\title{
The Properties of Intracellular Calcium Stores in Cultured Rat Cerebellar Neurons
}

\author{
James R. Brorson, ${ }^{1,2}$ David Bleakman, ${ }^{1}$ Simon J. Gibbons, ${ }^{1}$ and Richard J. Miller ${ }^{1}$ \\ Departments of 'Pharmacological and Physiological Sciences and ${ }^{2}$ Neurology, The University of Chicago, Chicago, \\ Illinois 60637
}

Cerebellar Purkinje neurons contain a remarkable array of cellular components potentially concerned with regulation of the free cytoplasmic $\mathrm{Ca}^{2+}$ concentration, $\left[\mathrm{Ca}^{2+}\right]_{i^{*}}$ These include high concentrations of $\mathrm{Ca}^{2+}$-binding proteins, inositol 1,4,5-triphosphate receptors $\left(I P_{3} R\right)$, and ryanodine receptors (RyR). The latter two molecules are thought to be associated with intracellular $\mathrm{Ca}^{2+}$ stores. We have examined the properties of such stores in cultured rat cerebellar neurons taken from $16 \mathrm{~d}$ rat embryos. In this system, about half of the neurons could be identified as Purkinje-like cells, as indicated by staining for the $\mathrm{Ca}^{2+}$-binding protein calbindin D-28k, as well as for $I P_{3} R$ and RyR. In double immunofluorescent staining, the IP $R$ and $R y R$ immunoreactivity primarily colocalized with the staining for calbindin. The cells responded to glutamate, kainate, and quisqualate with large increases in the somatic $\left[\mathrm{Ca}^{2+}\right]_{i}$ but failed to respond directly to NMDA (10-50 $\mu \mathrm{M})$. Furthermore, the neurons expressed active membrane conductances, repetitive action potential firing, and spontaneous firing patterns similar to those reported for cerebellar Purkinje neurons in vivo. Action potential firing produced changes in somatic $\left[\mathrm{Ca}^{2+}\right]$, that were quite small or absent in most cells. However, blocking spike repolarization with tetraethylammonium $(5 \mathrm{~mm})$ produced substantial transient elevations in somatic $\left[\mathrm{Ca}^{2+}\right]_{i}$ suggesting the expression of some $\mathrm{Ca}^{2+}$ channels in the somatic membrane. Caffeine $(10 \mathrm{~mm})$ released $\mathrm{Ca}^{2+}$ from intracellular stores in about one-half of the cultured neurons. This effect could be repeated if the stores were first reloaded by a depolarization-induced elevation in $\left[\mathrm{Ca}^{2+}\right]_{r}$ The effects of caffeine were reduced by prolonged application of ryanodine $(10 \mu \mathrm{M})$. We were also able to demonstrate that the caffeinesensitive $\mathrm{Ca}^{2+}$ stores could regulate electrophysiological events in some cells, altering patterns of spontaneous activity. Furthermore, in the presence of caffeine, $\left[\mathrm{Ca}^{2+}\right]_{i}$ sig-

\footnotetext{
Received May 13, 1991; revised July 12, 1991; accepted July 17, 1991.

This work was supported by PHS grants DA-02121 and MH-40165 and Digestive Diseases Core Grant 1-P30-DK42086-01 to R.J.M. J.R.B. was supported by NIH Grant T32-NS071113-14 and is a Howard Hughes Medical Institute Physician Research Fellow. D.B. was supported by a Fulbright fellowship and senior research fellowships from the Chicago Heart Association. S.J.G. was supported by a long-term postdoctoral fellowship from the Human Frontier Science Program. We express thanks to Wendy Scholz and James Holzwarth for assistance in developing and maintaining the cerebellar cultures; to Solomon Snyder, Audrey Bentley, Alan Sharpe, and Christopher Ross for providing antisera to the $\mathrm{IP}_{3}$ receptor; and to Peter McPherson and Kevin Campbell for providing antisera to the ryanodine receptor.

Correspondence should be addressed to James R. Brorson, Department of Pharmacological and Physiological Sciences, The University of Chicago, 947 East 58th Street, Chicago, IL 60637.

Copyright @ 1991 Society for Neuroscience $0270-6474 / 91 / 114024-20 \$ 05.00 / 0$
}

nals induced by an evoked spike train were larger and accompanied by long-lasting afterhyperpolarizations. We conclude that in addition to providing a releasable pool of $\mathrm{Ca}^{2+}$, the caffeine-sensitive stores also influence cellular events by their contribution to $\mathrm{Ca}^{2+}$ buffering.

Cerebellar Purkinje cells have been a focus of great interest for their unique electrophysiological properties and for their central role as the sole source of neuronal output from the cerebellar cortex. Patterns of spontaneous action potential (AP) firing, complex spikes with fast somatic $\mathrm{Na}^{+}$and longer dendritic $\mathrm{Ca}^{2+}$ components, and burst firing patterns have all been described in Purkinje cells (Llinas and Sugimori, 1980a; Gruol and Franklin, 1987). The receptor physiology of Purkinje cells has also been of particular interest. The synapses between granule cell parallel fibers and Purkinje cells are perhaps the most numerous in the CNS, exhibiting the interesting properties of long-term depression and facilitation (Sakurai, 1987; Hirano, 1990). These synapses are thought to be glutamatergic, mediated by nonNMDA reccptors. Indeed, Purkinje cells also show the unusual property of being devoid of NMDA receptors (Audinat et al., 1990). Plasticity at this synapse may involve cytoplasmic $\mathrm{Ca}^{2+}$ signals (Sakurai, 1990; but see also Hirano, 1990).

Purkinje cells are also distinguished by the variety of intracellular markers they express that are potentially involved in the regulation of the free cytoplasmic $\mathrm{Ca}^{2+}$ concentration, $\left[\mathrm{Ca}^{2+}\right]_{i}$. They express high levels of the $\mathrm{Ca}^{2+}$-binding proteins calbindin D-28k and parvalbumin (but not calretinin) (Rogers, 1989; Celio, 1990). They also stain strongly for the ryanodine receptor (RyR), which is thought to represent an intracellular $\mathrm{Ca}^{2+}$ release channel (Ellisman et al., 1990), as well as the inositol 1,4,5trisphosphate receptor $\left(\mathrm{IP}_{3} \mathrm{R}\right)$, thought to mark intracellular $\mathrm{Ca}^{2+}$ stores sensitive to $\mathrm{IP}_{3}$ produced by the metabotropic glutamate and possibly other receptors (Mignery et al., 1989; Ross et al., 1989; Maeda et al., 1990, 1991; Satoh et al., 1990; Masu et al., 1991). Several studics have examined the ultrastructural anatomy of these proteins, but little is known about their involvement in the physiology about Purkinje cells. $\mathrm{Ca}^{2+}$-binding proteins and intracellular $\mathrm{Ca}^{2+}$ stores may regulate Purkinje cell electrophysiology through the $\mathrm{Ca}^{2+}$ buffering capacity that they potentially provide, as well as through release of stored $\mathrm{Ca}^{2+}$ (Miller, 1991).

Much of the important work on Purkinje cells has been performed in cerebellar slice preparations that preserve synaptic connectivity and tissue architecture (Llinas and Sugimori, 1980a,b). However, dissociated cell culture systems provide ready access to individual cells for the application of drugs, for patch clamping, and for microfluorimetric measurements. Several in- 
vestigators have reported studies carried out on cultured cerebellar neurons (Gruol and Franklin, 1987; Gruol and Crimi, 1988; Yool et al., 1988; Hockberger et al., 1989a; Yuzaki et al., 1990; Sorimachi ct al., 1991). These ccrcbcllar ncuronal cultures have consisted of relatively small populations of Purkinje cells that are greatly outnumbered by other cerebellar neurons produced from the external germinal layer (EGL). These include basket, stellate, and granule cells. Neurons selected as Purkinje cells for electrophysiological study have been identified morphologically or immunocytochemically.

Although it seems likely that various types of intracellular $\mathrm{Ca}^{2+}$ storage sites exist in central neurons as they do in peripheral neurons, muscle cells, and other cell types, virtually nothing is known about their properties or the physiological roles of these entities in the brain. Therefore, we sought to prepare cultures of cerebellar Purkinje cells in relative isolation from other neuronal types, in order to be able to study the $\mathrm{Ca}^{2+}$ regulatory processes occurring in these cells. Altman and Bayer (1985a-c) have shown that in the development of the rat cerebellum the gencration of Purkinje cells is preceded only by that of the deep cerebellar nuclear neurons and is followed by the production of the Golgi cells and the spread of the EGL over the cortical surface. On embryonic day 16 (E16), most of the Purkinje cells have been formed, whereas the EGL does not appear until E17. We describe a culture system in which cerebella are taken from E16 rat embryos and in which the majority of neurons stain for immunocytological markers of authentic Purkinje cells, including calbindin, the $I_{3} R$, and the $R y R$. We have characterized the electrophysiological properties and glutamate receptor responsiveness of these neurons. Furthermore, we show that some of these cells respond to caffeine with mobilization of intracellular $\mathrm{Ca}^{2+}$ and that the caffeine-sensitive $\mathrm{Ca}^{2+}$ stores can participate in the regulation of electrical activity in certain neurons.

\section{Materials and Methods}

Neuronal culture. Dissociated primary cerebellar neuronal cultures in serum-free medium were performed with a bilaminar culture method similar to that described by Scholz et al. (1988) for culture of hippocampal neurons. One week prior to the date of neuronal culture, astrocytes were plated at low density in plastic dishes. Brains from newborn rat pups [postnatal day 1 (P1) or P2] were removed with sterile technique, and the cerebella and cerebral hemispheres were separated, stripped of meninges, and diced into $1-2 \mathrm{~mm}$ pieces. The tissue was incubated at $37^{\circ} \mathrm{C}$ in a $0.25 \%$ solution of trypsin (GIBCO) in $\mathrm{Ca}^{2+}$-free and $\mathrm{Mg}^{2+}$ free Hank's solution (Hank's) for $20 \mathrm{~min}$. DNase (Sigma) solution (1.5 $\mathrm{mg} / \mathrm{ml}$, in $\mathrm{Mg}^{2+}$-supplemented Hank's) was added at 1:50 dilution, and after 1-2 min the tissue was triturated. The trypsin was quenched by the addition of $10 \mathrm{ml}$ of Dulbecco's Modified Eagle's Medium (DMEM) (4500 mg/liter glucose, with L-glutamine and pyruvate) (JRH Inc.) supplemented with $10 \%$ fetal bovine serum (10\% FCS). After 4 min, the supernatant was removed and centrifuged. The pellet was resuspended in $2 \mathrm{ml}$ of Hank's. The cells were counted and diluted in 10\% FCS to $1 \times 10^{5} / \mathrm{ml}$. One milliliter of this cell suspension was added to $3 \mathrm{ml}$ of prewarmed $10 \% \mathrm{FCS}$ in each plate and incubated at $37^{\circ} \mathrm{C}$ in humidified $5 \% \mathrm{CO}_{2}$ atmosphere. One day later, the plates were washed and $4 \mathrm{ml}$ of DMEM supplemented with $10 \%$ horse serum (10\% HS) was placed in each plate.

One day prior to neuronal culturing, $15 \mathrm{~mm}$ diameter circular glass coverslips were prepared by rinsing in acetone and then in $95 \%$ ethanol and flaming. The coverslips were placed in $100 \mathrm{~mm}$ plastic Petri dishes. Threc paraplast "feet" were affixed to each cover slip. Filter-sterilized poly-L-lysine solution $(0.5-1 \mathrm{mg} / \mathrm{ml}$ in borate buffer) was pipetted onto each coverslip and allowed to dry overnight under UV light.

On the day of neuronal culturing, coverslips were rinsed four limes in filtered pure water. N2.1 medium was freshly prepared by supplementing DMEM with the following additions: insulin, $5 \mathrm{mg} / \mathrm{liter}$; progesterone, $20 \mathrm{nmol}$; putrescine, $100 \mu \mathrm{mol}$; selenium, $30 \mathrm{nmol}$; trans- ferrin, $100 \mathrm{mg} /$ liter; and ovalbumin, $1000 \mathrm{mg} /$ liter. The astrocyte plates were washed in filtered Hank's and preincubated with $4 \mathrm{ml}$ per plate of N2.1 medium. A pregnant Holtzman rat, gestational day 16, was anesthetized in ether, and the gravid uterus was removed. The embryos were extracted and, under a dissecting microscope, the brains were removed. At this embryonic stage, the cerebellum was partially covered by the overhanging midbrain tectum, but with careful dissection the metencephalon and attached cerebellum could easily be sectioned away from the midbrain and medulla. The cerebellar hemispheres were usually found to be partially fused at the midline. Since little gyral folding had yet developed at this age, the meninges could be easily pulled away and the cerebellum separated from the underlying pons at the lateral recesses of the fourth ventricle.

The cerebella were incubated in $4.5 \mathrm{ml}$ of Hank's with $0.5 \mathrm{ml}$ of trypsin solution (Worthington; $100 \mathrm{mg} / 10 \mathrm{ml}$ Hank's) for $20-25 \mathrm{~min}$ at $37^{\circ} \mathrm{C}$. The supernatant was aspirated off, the tissue was washed twice in $5 \mathrm{ml}$ of Hank's, and then $1.8 \mathrm{ml}$ of Hank's and $0.2 \mathrm{ml}$ of DNase solution were added to the tissue. It was triturated $5-10 \times$; then a flamenarrowed pipette was used to triturate until no visible tissue fragments were left. The cells were counted (typical yields, $0.6-0.8 \times 10^{6}$ cells/ cerebellum) and diluted in $10 \% \mathrm{HS}$ to $2 \times 10^{\mathrm{s}} \mathrm{cells} / \mathrm{ml}$. This cell suspension was pipetted onto the prepared coverslips (80-120 $\mu \mathrm{l}$ per coverslip, for a cell density of approixmately 150 cells per $\mathrm{mm}^{2}$ ), and the coverslips were incubated for $2-4 \mathrm{hr}$ to allow cell attachment. Then the coverslips were inverted and placed over the astrocyte layer in the prewarmed and astrocyte-conditioned medium.

Feeding was begun $2 \mathrm{~d}$ later by replacement of half of the medium in each plate with fresh N2.1. At this time, 2 drops of $5 \times 10^{-4} \mathrm{M}$ 5-fluoro-2'-deoxyuridine (FUDR; Sigma) solution was added to each plate (final concentration, approximately $5 \times 10^{-6} \mathrm{M}$ ) to arrest astrocyte proliferation at near-confluency. Subsequently, the cells were fed twice per week.

Immunocytochemistry. Immunocytochemical staining was performed using commercial avidin-biotin peroxidase complex kits (Vector) or fluorophore-labeled secondary antibodies (Jackson Immunolabs). Cultured cells were fixed at $37^{\circ} \mathrm{C}$ in $\mathrm{Ca}^{2+}$ - and $\mathrm{Mg}^{2+}$-free Hank's solution containing 3\% paraformaldehyde and $0.01 \%$ glutaraldehyde (glutaraldehyde was omitted for immunofluorescent staining). Cells were rinsed three times with PBS, permeabilized in $0.1 \%$ Triton X-100 PBS solution, rinsed, and blocked in $2 \%$ BSA in PBS (BSA/PBS) for $45 \mathrm{~min}$. Primary antibodies were diluted to the titers indicated in BSA/PBS and applied for $2-4 \mathrm{hr}$ at room temperature. For immunofluorescent stains, the cells were then blocked again with 5\% normal serum of the species in which the secondary antibody was raised for $30 \mathrm{~min}$. Secondary antibodies (biotin conjugated for immunoperoxidase stains and fluorophore conjugated for immunofluorescence) were diluted in BSA/PBS and applied for $45 \mathrm{~min}$ at room temperature. For immunoperoxidase stains, avidinbiotinylated peroxidase reagent was mixed according to kit instructions and applied for $45 \mathrm{~min}$, following which the cells were rinsed in BSA/ PBS and then Tris, and then developed with brief exposure to diaminobenzidine-hydrogen peroxide solution according to kit instructions. Immunofluorescent-stained coverslips were rinsed in BSA/PBS and Tris. Coverslips were wet mounted and viewed on a Nikon Photophot microscope. Immunofluorescent stains were viewed on a Leitz Diaplan fluorescent microscope.

Positively staining cells were counted by viewing wet-mounted coverslips in phase contrast at high power to count all cells in a field, and then switching to bright-field viewing to count stained cells. Only cells with intact extended neurites were counted as surviving neurons. Multiple adjacent fields were thus counted, to a total of 100 or more cells. For each count, the average of two simultaneously stained coverslips was used.

Affinity-purified rabbit $\mathrm{IP}_{3} \mathrm{R}$ antibody, the kind gift of Drs. Audrey Bentley, Alan Sharpe, Christopher Ross, and Solomon Snyder (Johns Hopkins University), was used at 1:50 dilution. The antisera to RyR, produced in guinea pig, were the gifts of Dr. Peter McPherson and Dr. Kevin Campbell (University of Iowa) and were used at dilutions of 1:500-1000. Antibody to GABA, used at 1:1000 dilution, was the gift of Dr. Henry Lec (University of Chicago). Mouse monoclonal antibody to calbindin D-28k was obtained from Sigma Chemical Co. and used at $1: 20,000$ dilution.

Electrophysiology. The tight-seal whole-cell configuration of the patchclamp technique (Hamill et al., 1981) was used for current-clamp and voltage-clamp recordings. Coverslips were mounted in a perfusion chamber and superfused with extracellular solution containing any drugs 
in the indicated concentrations. A cell was approached with a firepolished pipette containing the appropriate intracellular solution. For current-clamp recordings and for voltage-clamp measurements of $\mathrm{Na}^{+}$ or $\mathrm{K}^{+}$currents, extracellular solutions contained (in $\mathrm{mm}$ ) $\mathrm{NaCl}, 138$; $\mathrm{CaCl}_{2}, 2 ; \mathrm{MgCl}_{2}, \mathrm{I} ; \mathrm{KCl}, 3 ; \mathrm{HEPES}, 10$; glucose, $10 ; \mathrm{pH}$ adjusted to 7.4 with $\mathrm{NaOH}$; other agents were added to this solution as indicated. Intracellular solutions contained (in $\mathrm{mM}$ ) $\mathrm{K}^{+}$-gluconate, 145 , or $\mathrm{K}^{+}$acetate, 100 with $\mathrm{KOH} \mathrm{40;} \mathrm{Mg}^{2+}, 1$; HEPES, 10; di-Tris phosphocreatinine, 14; Mg-ATP, 3.6; $50 \mathrm{U} / \mathrm{ml}$ creatinine phosphokinase; and EGTA, 0.1 or 10 ; adjusted to $\mathrm{pH} 7.2$ with $\mathrm{KOH}$. Only $0.1 \mathrm{mM}$ EGTA was used in current-clamp recordings of caffeine effects, and EGTA was omitted in all simultaneous current-clamp and $\left[\mathrm{Ca}^{2+}\right]_{i}$ microfluorimetry recordings. For voltage-clamp measurement of $\mathrm{Ca}^{2+}$ currents, the intracellular solution contained $\mathrm{CsCl}$ substituting for $\mathrm{K}^{+}$-acetate and $\mathrm{KCl}$, and 10 mM EGTA; the extracellular solution contained (in mM) tetraethylammonium chloride (TEA Cl), 143; $\mathrm{CaCl}_{2}, 2 ; \mathrm{MgCl}_{2}, 1$; HEPES, 10 ; glucose, $10 ; \mathrm{pH}$ adjusted to 7.4 with TEA OH. Electrical recordings were made with an Axopatch 1D amplifier (Axon Instruments) or a List EPC-7 amplifier. Data aquisition was by a Spear 286 personal computer, making use of C-LAB (Indec Systems, Sunnyvale, CA)-based software generously provided by Dr. Ken P. Scholz, or on an Indec PDP-11, using software written in BAsIC-23 (Cheshire Data, Indec Systems). Capacitive compensation, series resistance compensation, and leak subtraction were performed for voltage-clamp traces. Traces were filtered by a low-pass eight-pole Bessel filter (Frequency Devices) and stored digitally. Cells were accepted if the cell resistance was greater than $100 \mathrm{M} \Omega$ (most were greater than $300 \mathrm{M} \Omega$ ) and the membrane potential was more negative than $-45 \mathrm{mV}$, and only if the holding current or resting potential was stable. All recordings were made at room temperature.

$\left[\mathrm{Ca}^{2+}\right]_{\mathrm{i}}$ microfluorimetry. Intracellular calcium concentration $\left(\left[\mathrm{Ca}^{2+}\right]_{i}\right)$ was measured using the $\mathrm{Ca}^{2+}$-sensitive fluorophore fura-2 (Molecular Probes). For $\left[\mathrm{Ca}^{2+}\right]$ microfluorimetry alone and for $\left[\mathrm{Ca}^{2+}\right]_{i}$ imaging, cells were loaded with fura- 2 by incubation with fura- 2 acetoxymethyl ester $\left(5 \mu \mathrm{M}\right.$ in standard buffer for $30 \mathrm{~min}$ at $37^{\circ} \mathrm{C}$ ) and then washed for 30 min at the same temperature. For simultaneous electrophysiological and $\left[\mathrm{Ca}^{2+}\right]_{i}$ microfluorimetry measurements, $100 \mu \mathrm{M}$ fura-2 pentapotassium salt was present in the patch pipette solution.

Coverslips (15 mm diameter), plated with cells, were mounted in the perfusion chamber, which was positioned on the opening of the microscope stage. A suitable neuron was identified, and the cell soma was aligned within the collimated viewfinder of the photomultiplier tube, as previously described (Thayer et al., 1988b). The cells were continuously superfused with an $\mathrm{Na}^{+}$- and $\mathrm{Ca}^{2+}$-containing buffer as detailed above. Drugs were added to the external solution. $\mathrm{Ca}^{2+}$-free solutions contained no added $\mathrm{Ca}^{2+}$ and were buffered with $20 \mu \mathrm{M} 1,2$-bis(2-aminophenoxy)ethane- $N, N, N^{\prime}, N^{\prime}$-tetraacetic acid (BAPTA). Emission was measured alternately at excitation wavelengths of $340 \mathrm{~nm}$ and $380 \mathrm{~nm}$, and the ratio of emission intensities was translated into the $\left[\mathrm{Ca}^{2+}\right]_{i}$ using a predetermined calibration curve. Rapid solution change in the cell superfusion system was obtained by maintaining low chamber fluid volume of $200-400 \mu \mathrm{l}$ and laminar flow perfusion of $2 \mathrm{ml} / \mathrm{min}$. The tubing between the large media reservoirs and the inlet to the chambers delayed the onset of the solution change by approximately $15 \mathrm{sec}$. Figures have been corrected for the perfusion delay.

Combined electrophysiology and $\left[\mathrm{Ca}^{3+}\right]_{\mathrm{i}}$ microfluorimetry. For combined current-clamp and $\left[\mathrm{Ca}^{2+}\right]_{i}$ measurements, the instrumentation and methods used have been described previously in detail (Thayer et al., 1988b). Background fluorescence was recorded after formation of a gigaseal but before breaking into the cell, thus accounting for fluorescence contributed by the fura- 2 in the pipette. Since the pipette approached the cell from above, the objective was focused below the pipette near the middle of the cell to minimize the pipette fluorescence. Fluorescent recordings were made from the cell soma alone. Full diffusion of the fura- 2 from the pipette into the cell occurred over a period of 1-3 min. Cells were rejected if the basal $\left[\mathrm{Ca}^{2+}\right]_{i}$ was above $200 \mathrm{~nm}$. Voltage traces measured with a List EPC-7 amplifier were filtered and stored digitally. Action potentials were evoked by brief current pulses $(0.5-2.5 \mathrm{nA}, 4 \mathrm{msec})$. The membrane potential aquisition rate was $1 / \mathrm{msec}$ in order to obtain combined fura-2/electrophysiological records over 4 sec periods; consequently, certain action potential traces display variable peak action potential heights due to this slow sampling rate.

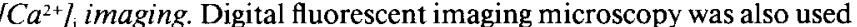
to determine the spatial distribution of $\left[\mathrm{Ca}^{2+}\right]_{i}$ in the cerebellar neurons. Coverslips containing cerebellar neurons were washed twice with HEPESbuffered Hank's balanced salt solution [HHBSS, pH 7.45, which contained (in mM) NaCl, $137 ; \mathrm{KCl}, 5.4 ; \mathrm{MgSO}_{4}, 0.41 ; \mathrm{MgCl}_{2}, 0.49 ; \mathrm{CaCl}_{2}$,
1.26; $\mathrm{KH}_{2} \mathrm{PO}_{4}, 7 ; \mathrm{H}_{2} \mathrm{O}, 0.64 ; \mathrm{NaHCO}_{3}, 3 ;$ glucose, 5.5; HEPES, 20]. Cells were loaded with fura-2 as above. Loading and completeness of deesterification were judged by stable fluorescent ratios. Coverslips were mounted in a laminar flow chamber (flow rate, $2-3 \mathrm{ml} / \mathrm{min}$ ) over an inverted stage fluorescent microscope (Nikon) and continuously perfused with HHBSS. All drugs were dissolved and delivered in the perfusate.

Cells were alternately illuminated with $340 / 380 \mathrm{~nm}$ light from a mercury source (Oriel). Emitted light was passed through a $480 \mathrm{~nm}$ barrier filter into a KS 1380 image intensifier coupled to a Dage model 70 vidicon camera. Images were then digitized as $256 \times 256$ pixel by eight bit arrays by an IBM PC/AT-driven Magiscan (Joyce-Loebl). Sequential $340 / 380$ excitation image pairs were ratioed and compared to a standard curve for free $\mathrm{Ca}^{2+}$ constructed from shallow solutions of known $\mathrm{Ca}^{2+}$ and fura-2 concentration, as previously described for this apparatus (Byron and Villereal, 1989). Nurnerical values reported are an average of $>50$ adjacent pixels. Exposure time for each wavelength was 500 $750 \mathrm{msec}$, with cells exposed to UV light only during data collection. Because of the long periods of data acquisition used to produce a ratioed image (1.5-3 sec), we underestimated the peak amplitude of the change in $\left[\mathrm{Ca}^{2+}\right]_{i}$ in these experiments.

For $\mathrm{Ca}^{2+}$-free experiments, $\mathrm{Ca}^{2+}$ was omitted and $0.1 \mathrm{~mm}$ EGTA added to the HHBSS. Cells were perfused with $\mathrm{Ca}^{2+}$-free HHBSS for 2 min prior to agonist application, a treatment previously shown in our laboratory to block $\left[\mathrm{Ca}^{2+}\right]_{i}$ responses to depolarizing stimuli in neuronal cultures. $\left[\mathrm{Ca}^{2+}\right]_{i}$ spike responses were calculated from the initial peak obtained with agonist treatment.

Materials. Fura-2 (pentapotassium salt or acetoxymethyl ester) was obtained from Molecular Probes Inc. (Eugene, OR); ryanodine and 6-cyano-7-dinitroquinoxaline-2,3-dione (CNQX) were obtained from Research Biochemicals Inc. (Natick, MA). Other chemicals, except as indicated, were obtained from Sigma Chemical Co. (St. Louis, MO).

\section{Results}

The culture system employed produced good development and survival of the cerebellar neurons. Cultured neurons rapidly put forth processes (Fig. 1A), which by $7 \mathrm{~d}$ in vitro (DIV) grew to a dense interconnecting network. The neurons were initially rather uniform in size and morphology, with somatic diameters of 10-12 $\mu \mathrm{m}$ (Fig. $1 A$ ). After several weeks, a population of larger neurons grew to $20-25 \mu \mathrm{m}$ in somatic diameter, with broad proximal dendrites (Fig. $1 B-D$ ). Morphological development of the neurons included a variety of shapes, some with the round or flask-shaped soma and single asymmetric broad primary dendritic tree, typical of Purkinje cells in vivo (Fig. $1 D-F$ ), and others with two or three primary dendrites. Ongoing neuronal death occurred, but substantial numbers of neurons survived for 4 weeks or more, and some up to several months. If the feeding layer of astrocytes was omitted, all neurons died during the second week of culture. Occasional astrocytes, numbering about one-tenth of the neuronal number, grew on the coverslips as well.

\section{Immunocvtochemistry}

Calbindin D-28k, a $\mathrm{Ca}^{2+}$-binding protein, is a specific marker for Purkinje cells within the cerebellum (Legrand et al., 1983; Rogers, 1989; Celio, 1990; Sequier et al., 1990). A monoclonal antibody to calbindin D-28k was found by immunocytochemical staining to bind specifically at high titer $(1: 20,000)$ to about one-half of the cultured cerebellar neurons from E16 rat embryos (Fig. 2). The distribution of calbindin staining was one of uniform dark staining throughout the cell soma and dendritic tree, including the nucleus and distal dendrites. When cells of 6-15 DIV were stained, $55 \pm 2 \%$ of neurons stained darkly for calbindin $(n=6)$. As has been described for in vivo development (Legrand et al., 1983), calbindin staining increased over the first 

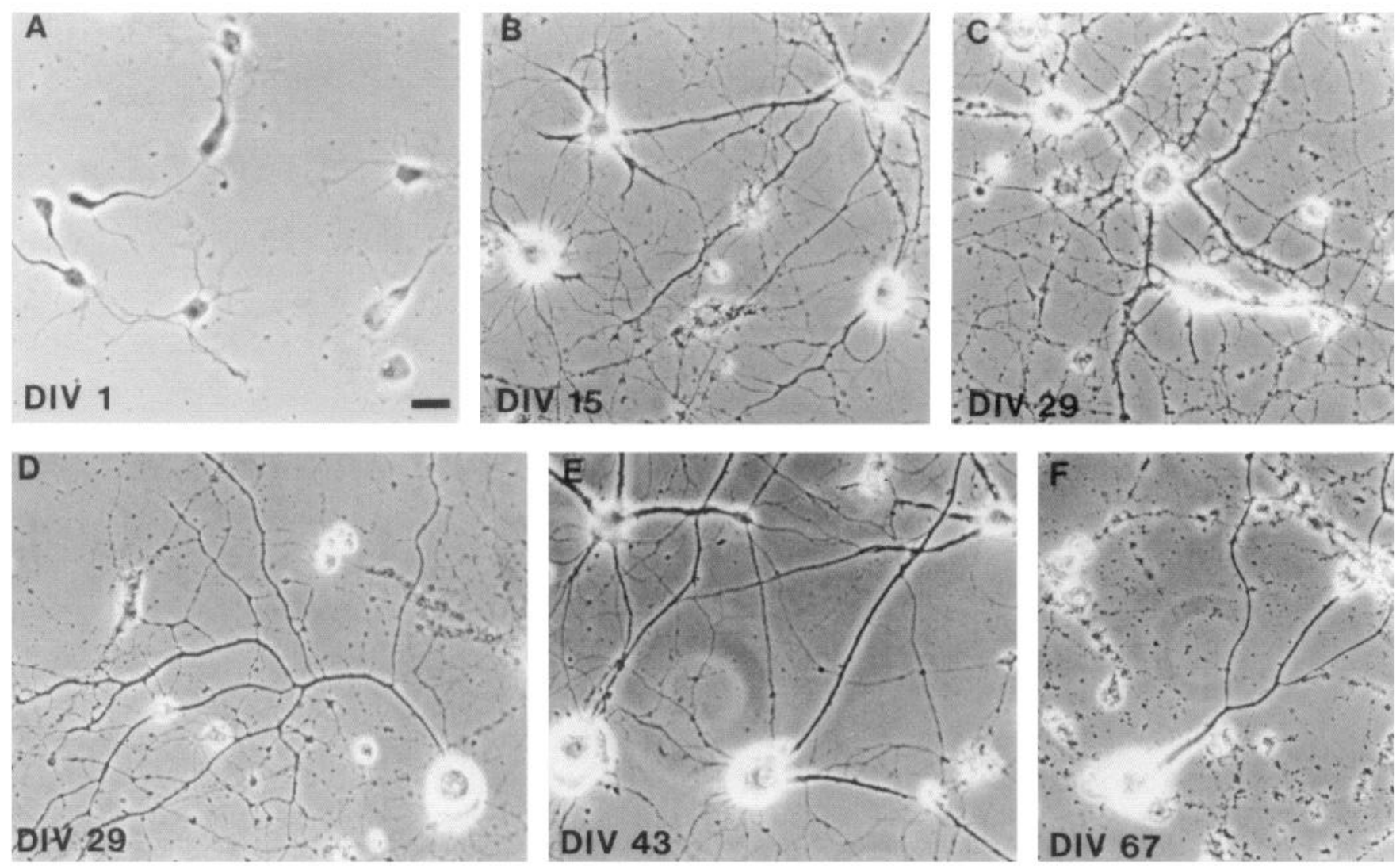

Figure 1. Cerebellar cultures. The in vivo appearance of the E16 cerebellar neuronal cultures as they developed is shown for cultures of ages from 1 to 67 DIV. $A$, Cells at 1 DIV were small and rather uniform in morphology and were extending multiple fine neurites. $B$, By 15 DIV, the neurons were larger and a complicated network of dendritic and axonal processes covered the surface of the coverslip. Most large neurons had multiple primary dendrites. $C$ and $D$. At 29 DIV, the neurons had grown still larger, with cell somas up to $25 \mu \mathrm{m}$ in diameter. Many large neurons still had multiple primary dendrites and pear-shaped or fusiform somatic shapes $(C)$, but some exhibited a more typical Purkinje cell morphology with a large round soma and a long, branching single primary dendrite $(D)$. E. At 43 DIV, neurons were sparse in distribution, but most of the remaining large neurons were of the Purkinje morphology. F, At 67 DIV, the rare surviving large neurons generally showed a well-developed Purkinje celllike morphology. Scale bar, $20 \mu \mathrm{m}$ (the scale is the same for all photographs in Figs. 1-4).

week as the E16 cultures developed in vitro. Staining was light in cells of age $0-1$ DIV, with only $27 \%$ of cells staining, and the staining appearing much lighter than in older cells. Between 0 and 5 DIV, an increasing proportion of cells stained and staining became more intense. By 6 DIV, about half of neurons stained (Fig. 2A). From 6 to 53 DIV, the fraction staining remained approximately constant, with staining becoming quite intense in most positive cells after 2 weeks in culture (Fig. $2 B, C$ ). Some calbindin-positive cells stained more lightly, but separation from calbindin-negative cells, which were absolutely devoid of staining, was clear with this antibody (see Fig. $2 A$ ). The morphology of the calbindin-positive cells was initially similar to that of most of the other neurons present. After approximately 1-2 weeks, most of the large neurons in the cultures were calbindin positive, particularly those with a large round soma and a single primary dendrite. However, a fair amount of variability in the morphology of the calbindin-positive neurons remained, with some positive cells retaining multiple primary dendrites (Fig. $2 B$ ). In later weeks, calbindin-positive cells were more consistently large round neurons with a single long, highly branched primary dendrite (Fig. 2C,D,E).

In order to examine the dependence of the identity of the cultured cells on the embryonic age of the rats from which the cerebella were taken, a series of cultures was performed, following the same method, using rats with developmental ages ranging from E16 to P1. Cultures taken later in embryonic life showed progressively smaller fractions of calbindin-positive cells, as greater numbers of calbindin-negative small neurons appeared (Fig. $2 F$, cultured on E21). The size and morphology of the calbindin-positive, putative Purkinje cells remained similar across all these cultures. Figure 3 shows representative data from a series of cultures, with the percentage of calbindin-positive neurons dropping from 55\% in the E16 cultures to less than 5\% by E19, and less than $1 \%$ in the cultures taken from newborn pups. Similar trends were found in two other series of cultures. The progressively decreasing representation of Purkinje cells in cultures performed on successive embryonic days is consistent with expectations from the embryologic data described above Altman and Bayer, 1985a-c), which would predict an increasing representation of interneurons derived from the EGL in cultures taken from older embryos.

Other immunocytochemical characteristics of the E16 culture system also suggest a high representation of Purkinje cells. In Figure $4, A$ and $B$, neuronal staining for GABA is shown. In the E16 cultures, $86 \%$ of neurons stained for GABA. The occasional GABA-negative neurons (Fig. $4 B$, arrows) included both some very large cells, which could correspond to deep cerebellar nuclear cells, and a few smaller neurons. An affinity-purified antibody to the $\mathrm{IP}_{3} \mathrm{R}$ (Peng et al., 1991) was found to label most of the large cultured neurons. In Figure $4 C$, the specific staining 

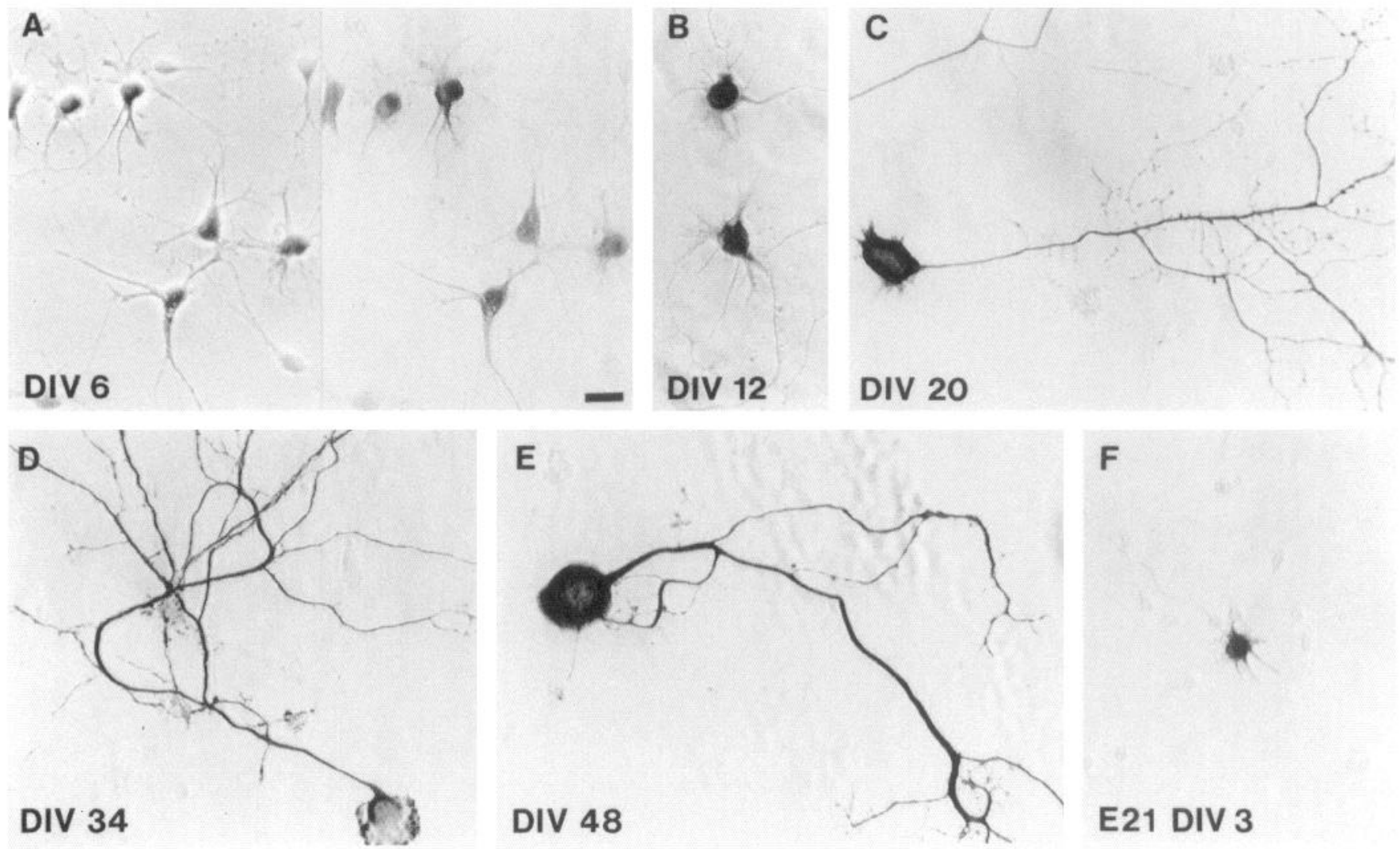

Figure 2. Calbindin staining. A monoclonal antibody to calbindin D-28k was used at 1:20,000 to stain specifically calbindin-containing neurons. $A$, In E16 DIV 6 cultures, comparison of phase-contrast and bright-field views of the same fields shows the high specificity of staining, with positive cells staining darkly and negative cells barely visible in the bright-field image. There was little morphologic differentiation between the calbindinpositive and the negative neurons at this stage. $B$, At 12 DIV, calbindin-positive neurons were larger and the distribution of the dendritic trees began to appear asymmetric. $C$, Some neurons at 20 DIV began to show a typical Purkinje morphology, with a rather round large soma and a long single primary dendrite. $D$ and $E$, At 34 and 48 DIV, calbindin-positive Purkinje cells exhibited large, round, flatly adherent soma with a single long primary dendrite giving off multiple branches and terminals. $F$, In an E21 DIV 3 culture, the calbindin-positive cells were greatly outnumbered by the smaller calbindin-negative cells, such as are shown in this mixed phase-contrast/bright-field image. Scale bar, $20 \mu \mathrm{m}$.

of several large neurons is visualized by comparison of the brightfield image to the phase-contrast image of a field of E16 DIV 8 cells. Antibody to the $\mathrm{IP}_{3} \mathrm{R}$ stained $57 \pm 2 \%$ of neurons $(n=$ 3). $I P_{3} R$ staining was different in intracellular distribution than that of staining for calbindin or GABA, being most evident in the cytoplasm to one side of the eccentrically located cell nucleus; there was lighter staining of the proximal dendrites. Staining for $I_{3} R$ in cultures taken from brains in later stages of development showed increased numbers of $\mathrm{IP}_{3} \mathrm{R}$-negative smaller neurons (Fig. 4D). Sequential cultures showed a decreasing fraction of $\mathrm{IP}_{3} \mathrm{R}$-positive cells paralleling the decreasing staining for calbindin with increasing embryonic age of the cultured cerebella (Fig. 3), which is consistent with the reported localization of $\mathrm{IP}_{3} \mathrm{R}$ to cerebellar Purkinje cells (Ross et al., 1989; Satoh et al., 1990). As negative controls, cultures of cerebellar granule cells taken from 1-week-old rat pups did not stain for calbindin or for $\mathrm{IP}_{3} \mathrm{R}$ (not shown). To characterize further the identity of the $\mathrm{IP}_{3} \mathrm{R}$-staining neurons, double fluorescent staining for calbindin and $\mathrm{IP}_{3} \mathrm{R}$ was performed $(n=3)$ (Fig. $\left.5 A\right)$. Most $(81 \%)$ of the calbindin-positive cells also stained for $\mathrm{IP}_{3} \mathrm{R}$ (large arrow, Fig. $5 \mathrm{~A}$ ). However, a population of the calbindin-negative cells also stained for $\operatorname{IP}_{3} \mathrm{R}$ ( $33 \%$ of the neurons positive for $\mathrm{IP}_{3} \mathrm{R}$ ), among them some of the brightest-staining cells for $\mathrm{IP}_{3} \mathrm{R}$.
Purkinje cells are also reported to contain the high-affinity RyR (Ellisman et al., 1990; McPherson and Campbell, 1990). This protein is thought to be a $\mathrm{Ca}^{2+}$-permeable channel that allows $\mathrm{Ca}^{2+}$ to be released from a population of intracellular stores (reviewed in Miller, 1991). In particular, the RyR may be involved in the process of $\mathrm{Ca}^{2+}$-induced $\mathrm{Ca}^{2+}$ release in muscle and peripheral neurons. We used several antisera raised in guinea pigs against the high-affinity RyR to identify the RyR in the cultured cells. Immunofluorescent staining with the RyR antisera revealed a diffuse light staining of all cells, but stronger positive immunofluorescence of $59 \%$ of neurons (Fig. $5 B$ ). Staining for the RyR seemed to be homogeneous in the positive cells, including the nuclear areas and dendritic processes; this distribution was distinctly different from that of the $\mathrm{IP}_{3} \mathrm{R}$. Some crossreaction with the cell structural protein spectrin is found using these antisera (P. McPherson, personal communication), so it is not clear whether the low-level diffuse staining seen represented background staining of cytostructural elements or low levels of RyR expression in these cells. When double immunofluorescent staining for calbindin and RyR was performed, it showed that almost all (97\%) of the calbindin-positive cells were included within the group staining strongly for RyR, but some calbindin-negative neurons were also included $(22 \%$ of the neu- 


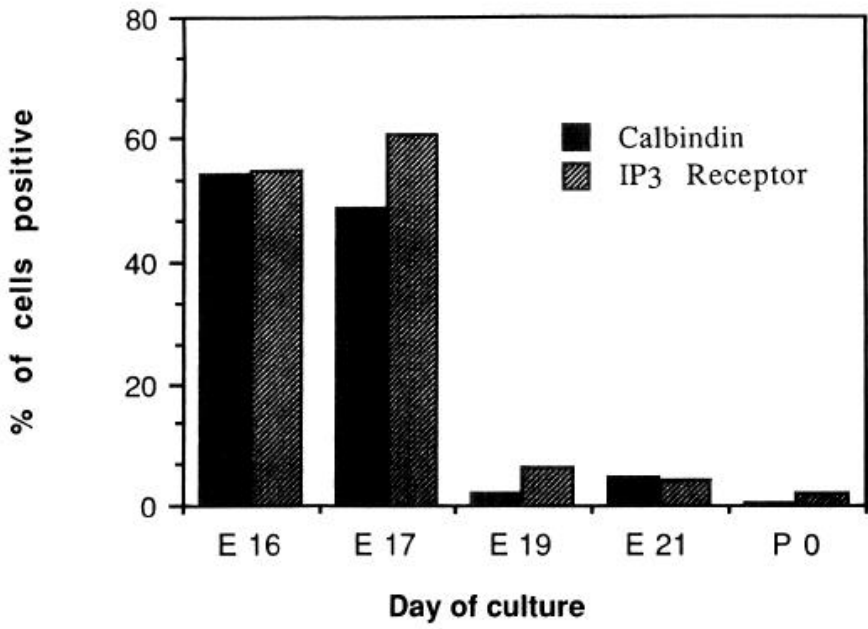

Figure 3. Effect of developmental age on cultured cells. In order to determine the influence of the age of the rat embryos from which cerebella were taken on the contents of resulting cultures, sequential cultures from rat embryos of E16 through P0 were made. Simultaneous staining of these sequential cultures for calbindin and for $\mathrm{IP}_{3} \mathrm{R}$ was then performed. For both antigens, about $50-60 \%$ of neurons in E16 cultures stained positively, but the positive fraction dropped rapidly after E17 to $5 \%$ or less in E19 and E21 cultures, and down to less than $1 \%$ in cultures from newborn pups. Two other such culture series were performed for calbindin staining, showing similar results.

rons staining brightly for RyR). Thus, by this method, the calbindin-positive neurons were largely a subset of the cells staining for either the $\mathrm{IP}_{3} \mathrm{R}$ or the RyR.

In summary, the majority of neurons in the E16 cultures stained for several different markers of Purkinje cells, including calbindin, $\mathrm{IP}_{3} \mathrm{R}, \mathrm{RyR}$, and GABA. The identity of the cells positive for $\mathrm{IP}_{3} \mathrm{R}$ or RyR but negative for calbindin is unclear, but it has been reported that in developing rat cerebella there is a transient expression of subsets of Purkinje cells that are calbindin negative (Wassef et al., 1985). It may be that some of the ontogenetic Purkinje cells remain calbindin negative in these dissociated cultures. Some of the remainder of the neurons are probably deep cerebellar nuclear cells, since these are generated in the cerebellum on E14, and others may be cerebellar interneurons such as Golgi neurons, since these are said to be produced soon after E16. It is possible that progenitor cell differentiation in vitro may give rise in the cultures to some cell types not expressed in vivo at age E16, particularly those produced soon after E16. Since the EGL from which the granule cells are produced in the late first week of postnatal life (Altman and Bayer, 1985c) does not begin to spread over the cerebellum until E17, one would not expect the E16 cultures to contain granule cells, and small neurons of the granule cell morphology were not seen.

\section{Glutamate receptors}

A further characteristic of Purkinje cells in many preparations is a lack of the NMDA type of glutamate receptor, despite responsiveness to agonists of the kainate (KA) and $\alpha$-amino-3hydroxy-5-methylisoxazole propionate (AMPA) classes of glutamate receptors (Audinat et al., 1990; Perkel et al., 1990; Llano et al., 1991; but see also Garthwaite et al., 1987; Krupa and Crepel, 1990). We therefore examined the effects of glutamate agonists in our cultured cells using fura- $2\left[\mathrm{Ca}^{2+}\right]_{i}$ microfluorime-
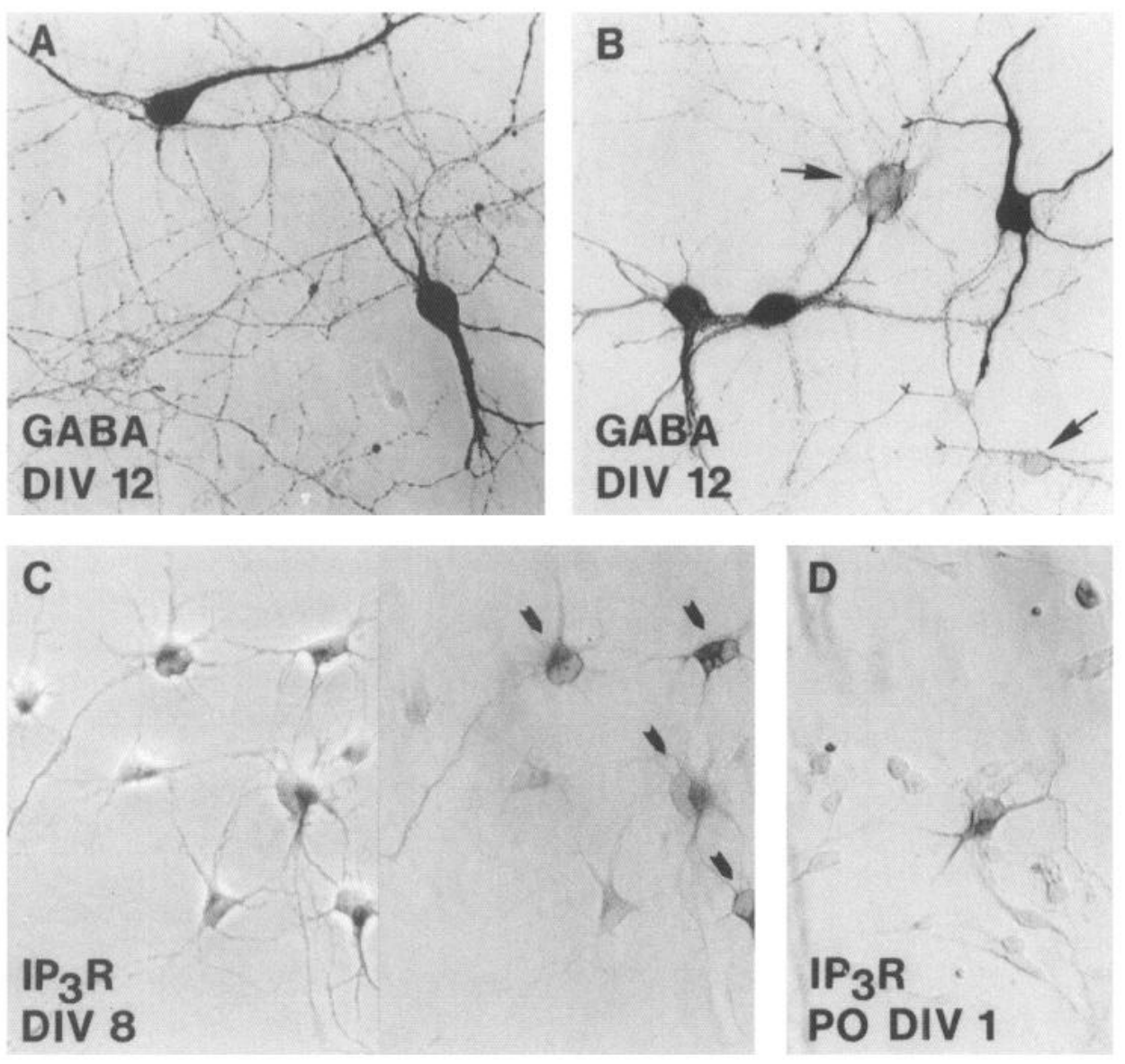

Figure 4. GABA and $\mathrm{IP}_{3}$ receptor staining. $A$ and $B$, Staining for GABA in E16 cultures produced dark uniform staining of most $(86 \%)$ of the neurons, large and small, but with occasional neurons $(B$, arrows) remaining clearly negative. $C$, Staining with an affinitypurified antibody to the $\mathrm{IP}_{3} \mathrm{R}$ in DIV 8 cells revealed positive staining of the large neurons (arrows). Comparison of phase-contrast and bright-field images shows the specificity of positive staining over low background levels. The distribution of staining within the neurons spared nuclear areas, primarily concentrating in somatic cytoplasm alongside the eccentrically located nuclei and extending into proximal dendrites. $D$, In cultures taken from older animals, only the occasional large neurons were positive for $\mathrm{IP}_{3} \mathrm{R}$ staining, the many small neurons being entirely negative for $\mathrm{IP}_{3} \mathrm{R}$. In this view of a P0 culture, a large $\mathrm{IP}_{3} \mathrm{R}$ neuron is surrounded by a number of smaller unstained neurons. The degenerating large neuron in the upper right is also $\mathrm{IP}_{3} \mathrm{R}$ positive. 

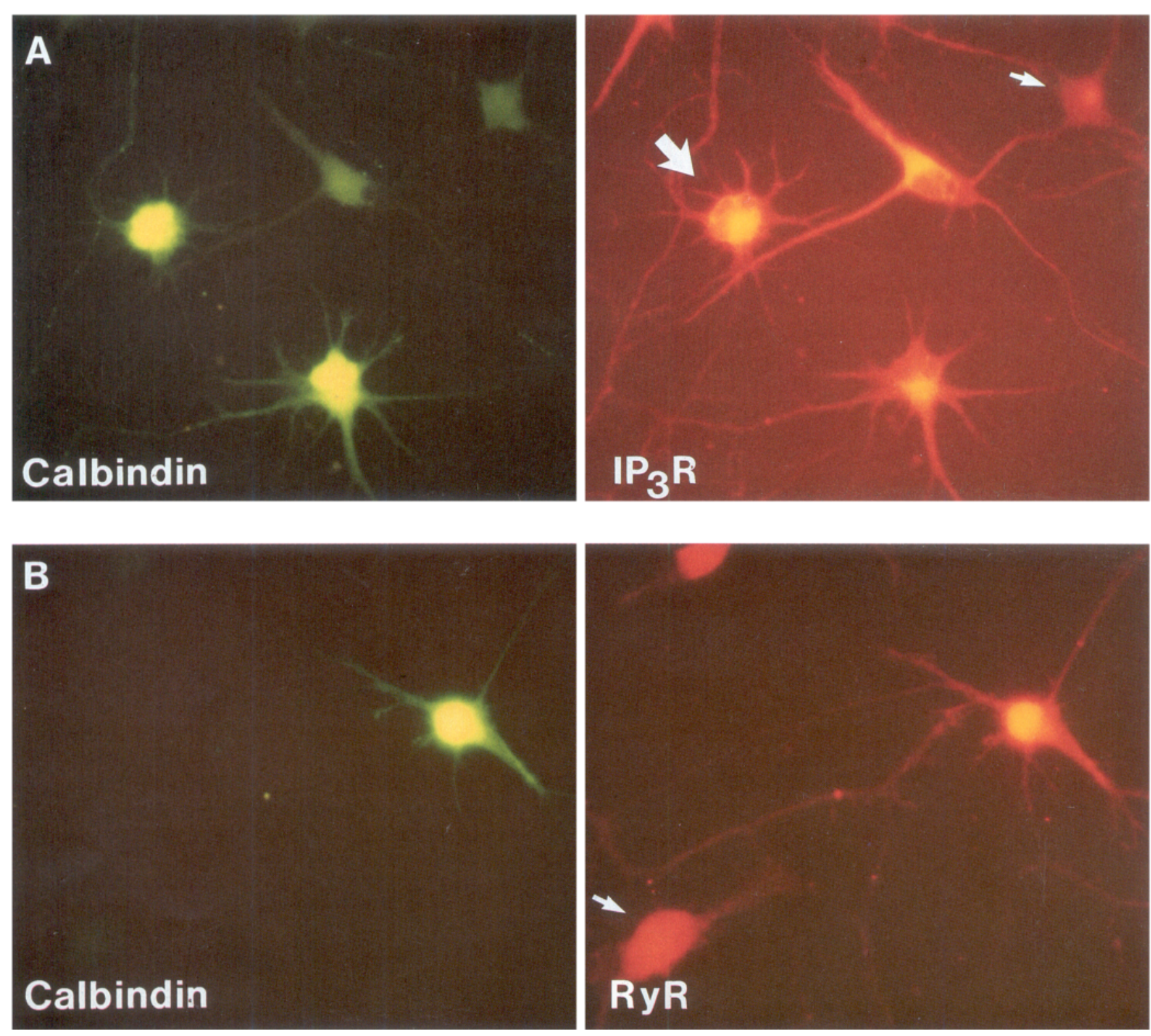

Figure 5. Double immunofluorescent staining for calbindin and the $\mathrm{IP}_{3} \mathrm{R}$ or the RyR. A, Double immunofluorescent staining for calbindin and IP ${ }_{3} \mathrm{R}$ used fluorescein isothiocyanate (FITC)-conjugated anti-mouse secondary antibody to label the calbindin staining and rhodamine isothiocyanate (RITC)-conjugated anti-rabbit antibody to label the $\mathrm{IP}_{3} \mathrm{R}$ staining. Shown here is staining of E16 DIV 8 cerebellar neurons (400 $\times$ magnification). Autofluorescence allows visualization of negative soma in these views. Calbindin staining specifically identified calbindin-positive cells, most of which were also positive for the $\mathrm{IP}_{3} \mathrm{R}$ (large arrow). Some of the calbindin-negative cells, however, were also brightly positive for $\mathrm{IP}_{3} \mathrm{R}$, and some cells were negative for both antigens (small arrow). The intracellular distributions of the two antigens were clearly different, with the $\mathrm{IP}_{3} \mathrm{R}$ sparing nuclear areas, as in immunoperoxidase staining. $B$, Immunofluorescence was also used with an antibody to the RyR, produced in guinea pig and labeled with an RITC-conjugated anti-guinea pig secondary antibody. Double labeling for the RyR and for calbindin (with FITC anti-mouse secondary antibody) is shown here, again in E16 DIV 8 neurons (500× magnification). Calbindin staining was again specific. RyR staining was less specific, with all cells exhibiting some degree of fluorescent labeling (small arrow). Certain neurons clearly were more brightly labeled, and these brightly RyR-staining neurons included almost all of the calbindin-positive neurons, such as the calbindin-positive neuron shown here. Staining was uniform throughout the soma and extended into the dendrites (photographic reproduction limits the appreciation of immunofluorescence in the thin processes). Some calbindin-negative neurons stained brightly for the RyR as well.

try. Cultures of various ages, from 5 to 50 DIV, were examined. Neurons of large size and morphology consistent with that of the calbindin-staining population were selected for study. Cell viability was assessed by brief application of $50 \mathrm{~mm} \mathrm{~K}^{+}$solution, which typically induced a rapid rise in somatic $\left[\mathrm{Ca}^{2+}\right]_{i}$, followed by a relatively rapid buffering of the $\left[\mathrm{Ca}^{2+}\right]_{i}$ back to basal levels with little or no suggestion of a plateau phase in the buffering
(Fig. 6) $(n=39)$. All cells tested responded to $10 \mu \mathrm{M}$ glutamate $(n=25)$, to $10 \mu \mathrm{M} \mathrm{KA}(n=47)$, and to $10 \mu \mathrm{M}$ quisqualate (Quis) $(n=38)$, from the first week in cultured life through the oldest cells tested (Figs. $6 A, B ; 7 A$ ). Such responses were reduced by $10 \mu \mathrm{M}$ CNQX. Responses to $50 \mathrm{~mm} \mathrm{~K}^{+}$and $\mathrm{KA}$ were not abolished by TTX $(1 \mu \mathrm{M})$, indicating that they did not depend on synaptic interactions between cells. 
Despite repeatable responses of $\left[\mathrm{Ca}^{2+}\right]_{i}$ to $50 \mathrm{mM} \mathrm{K}^{+}$or $\mathrm{KA}$ stimuli, eight cells showed no response to NMDA (10-50 $\mu \mathrm{M})$ when tested in the presence of TTX $(1 \mu \mathrm{M})$ to block axonal transmission and synaptic release (Fig. $6 A)$. Some cells $(n=10)$ of greater than 1 week of age in culture showed very small responses to NMDA (10 or $50 \mu \mathrm{M})$, even in TTX. However, these could be completely abolished with the addition of CNQX $(10 \mu \mathrm{M})$ (Fig. $6 B$ ), suggesting that these responses too were synaptically mediated. Similarly, when glutamate agonists were applied to current-clamped cells, large depolarizing responses to KA $(10 \mu \mathrm{M})$ were contrasted with complete lack of responsiveness to NMDA $(50 \mu \mathrm{M})$ in the presence of CNQX $(n=3$; not shown). We did observe some cells that did not fit this pattern. These cells exhibited $\left[\mathrm{Ca}^{2+}\right]_{i}$ responses to NMDA $(10$ or $50 \mu \mathrm{M})$ even in TTX and CNQX (5 $\mu \mathrm{M}$ or $10 \mu \mathrm{M})(n=6)$ (Fig. 6C). In these cells, responses to NMDA were generally larger and were fully blocked by aminophosphonovalerate $(50 \mu \mathrm{M})$. These findings indicate that the majority of neurons in these cultures (21 of 27 cells tested) are KA and Quis sensitive but not directly responsive to NMDA, consistent with the known phenotype of Purkinje neurons. A minority of neurons would seem to be NMDA sensitive, which is consistent with the expectations of a representation of deep cerebellar nuclear neurons in the culturcs.

\section{Intracellular $\mathrm{Ca}^{2+}$ stores}

Since many cells expressed receptors associated with intracellular $\mathrm{Ca}^{2+}$ stores (see above), we sought to demonstrate mobilization of $\mathrm{Ca}^{2+}$ from these stores. We used Quis in $\mathrm{Ca}^{2+}$-free solution and the specific agonist trans-1-aminocyclopentane1,3-dicarboxylic acid ( $t$-ACPD) to test for responses mediated by the metabotropic glutamate receptor, which is thought to be linked to $\mathrm{IP}_{3}$-sensitive intracellular $\mathrm{Ca}^{2+}$ stores in Purkinje cells. Surprisingly, neither agonist induced demonstrable $\mathrm{Ca}^{2+}$ mobilization $(n=13)$ (Fig. 7A). Four neurons failed to respond to Quis $(10 \mu \mathrm{M})$ in $\mathrm{Ca}^{2+}$-free external solution but responded briskly to Quis in $2 \mathrm{mM} \mathrm{Ca}^{2+}$. Nine cells failed to respond to $t$-ACPD ( $n=3$ at $10 \mu \mathrm{M}$ and $n=6$ at $200 \mu \mathrm{M}$ ).

In contrast, caffeine $(10 \mathrm{mM})$ effectively mobilized $\mathrm{Ca}^{2+}$ from intracellular stores. In 103 of 157 cells examined (66\%), caffcinc produced a transient elevation of somatic $\left[\mathrm{Ca}^{2+}\right]_{i}$ by at least 25 nM. Figure $7 B$ shows a typical caffeine response. The average size of the response in $\left[\mathrm{Ca}^{2+}\right]_{i}$ (in 17 randomly selected single cells from different coverslips) was $269 \pm 41 \mathrm{nM}$, which was $38.5 \%$ of the average response to $50 \mathrm{mM} \mathrm{K}^{+}$in the same cells; however, there was no evident correlation between the size of the response to caffeine and that to $50 \mathrm{~mm} \mathrm{~K}^{\prime}$ in an individual cell. These caffeine responses lasted $26 \pm 2 \mathrm{sec}$, independent of the duration of caffeine exposure. They reached a peak $\left[\mathrm{Ca}^{2+}\right]_{i}$ within a few seconds and then generally returned to baseline more rapidly than did the $50 \mathrm{~mm} \mathrm{~K}^{+}$responses. The caffeine

Figure 6. Glutamate receptors. Fura-2-based $\left[\mathrm{Ca}^{2+}\right]_{i}$ microfluorimetry was used to assess responses to agonists of glutamate receptors in these cells. For the experiments shown, TTX $(0.5-1.0 \mu \mathrm{M})$ was used throughout to block synaptic transmission that may have contributed to responses. $A$, In a DIV 10 neuron, rapid increases in somatic $\left[\mathrm{Ca}^{2+}\right]_{i}$ were generated by exposure to depolarizing concentrations of $\mathrm{K}^{+}(50 \mathrm{mM})$, followed by fairly rapid return of somatic $\left[\mathrm{Ca}^{2+}\right]_{i}$ to a resting level. Similar responses were generated by KA $(10 \mu \mathrm{M})$. All cells tested $(n=$ 16) responded to KA. In contrast, NMDA $(10 \mu \mathrm{M})$, in $\mathrm{Mg}^{2+}$-free and
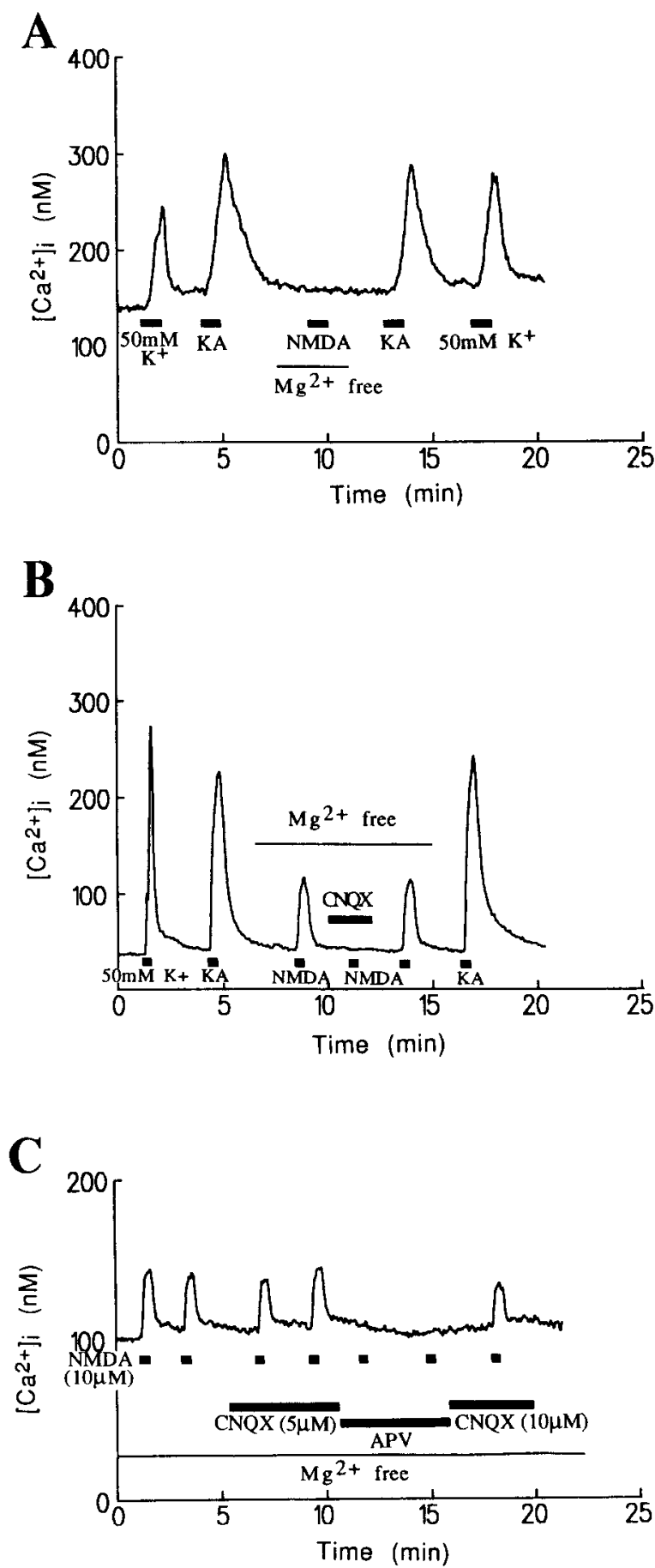

glycine-supplemented medium, failed to cause any elevation in $\left[\mathrm{Ca}^{2+}\right]$ ( $n=8$ such cells failed to respond to NMDA in TTX-containing medium). $B$, Again, large reversible responses to $50 \mathrm{mM} \mathrm{K}^{+}$and to $\mathrm{KA}(10$ $\mu \mathrm{M})$ were generated in the soma of a cell in a DIV 24 culture. In this cell, despite TTX blockade, NMDA $(50 \mu \mathrm{M})$ produced a moderate response in $\left[\mathrm{Ca}^{2+}\right]_{i}$ that was completely blocked by the addition of CNQX $(10 \mu \mathrm{M})$, suggesting that this was not a direct response to NMDA but rather an indirect presynaptic response, mediated by intervening CNQXsensitive synapses. [NMDA responses were fully blocked by CNQX $(10$ $\mu \mathrm{M})$ in 10 cells, 5 at $10 \mu \mathrm{M}$ NMDA and 5 at $50 \mu \mathrm{M}$ NMDA. The cell shown was the largest NMDA response obtained that was sensitive to CNQX.] $C$, Some cells $(n=6)$ showed NMDA responses that were not CNQX sensitive. Such cells generally had larger responses to NMDA and responded at lower concentrations. In the experiment shown (DIV 26), moderate responses to NMDA $(10 \mu \mathrm{M})$ were not blocked by CNQX at 5 or $10 \mu \mathrm{M}$ but were fully blocked by APV $(50 \mu \mathrm{M})$. 

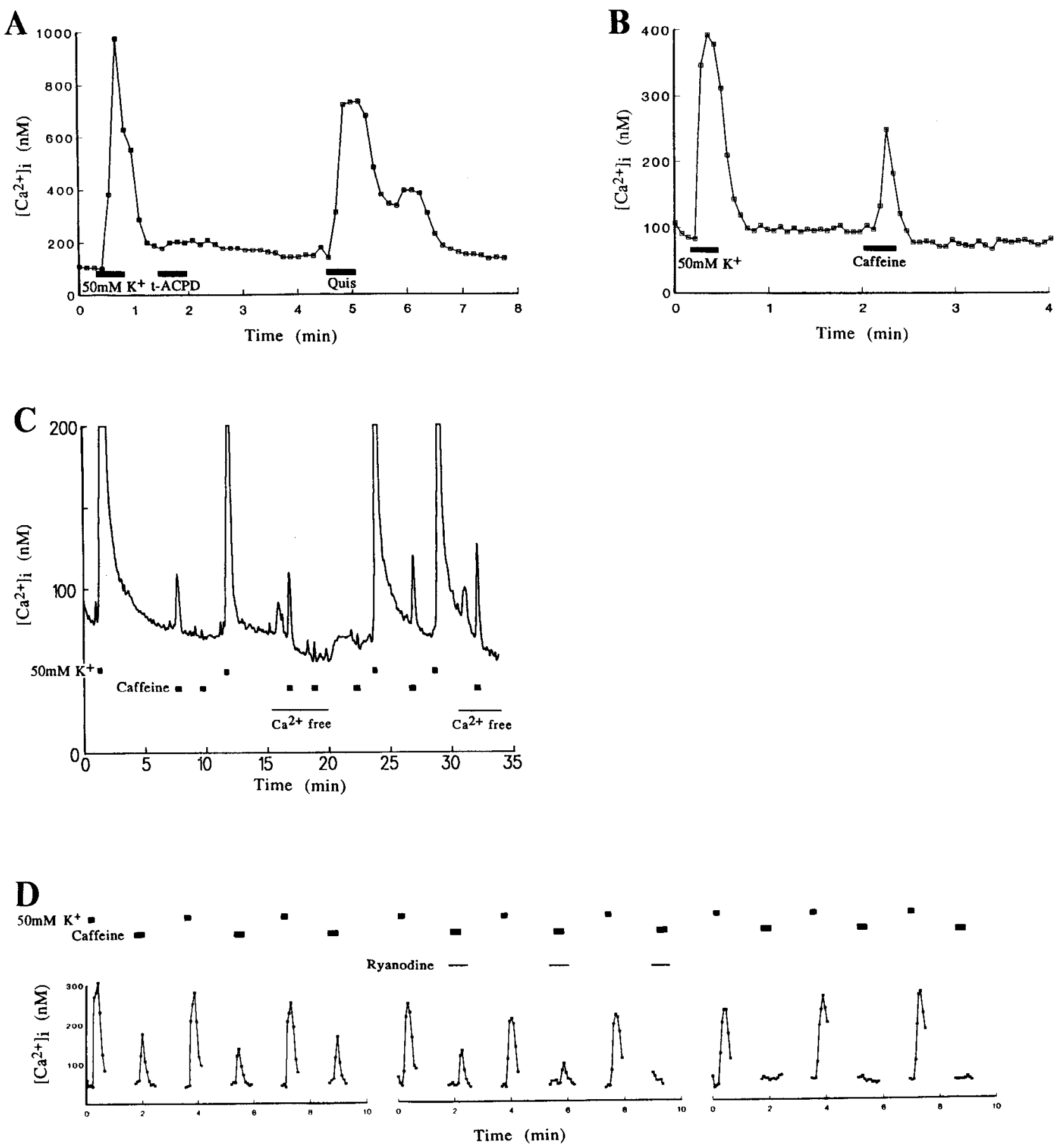

Figure 7. $\mathrm{Ca}^{2+}$ release from intracellular stores. $A$, Digital fluorometric imaging was used to screen for $\mathrm{Ca}^{2+}$ mobilization by the metabotropic glutamate receptor. Shown is the $\left[\mathrm{Ca}^{2+}\right]_{i}$ averaged over the soma of an imaged cell, showing a large $\mathrm{Ca}^{2+}$ influx in response to a depolarizing $\mathrm{K}^{+}$ concentration, but no definite response to $t$-ACPD $(10 \mu \mathrm{M})$, a specific agonist of the metabotropic receptor. The equivocal $\left[\mathrm{Ca}^{2+}\right]_{i}$ increase shown here is the largest change in $\left[\mathrm{Ca}^{2+}\right]_{i}$ observed in 13 cells; no cell showed a definite response to this metabotropic agonist. In contrast, Quis (10 $\left.\mu \mathrm{M}\right)$ evoked a brisk increase in $\left[\mathrm{Ca}^{2+}\right]_{i} . B$, Caffeine induced $\mathrm{Ca}^{2+}$ mobilization in 103 of the 157 cells tested (66\%). A typical response is shown, with a moderate transient $\left[\mathrm{Ca}^{2+}\right]_{i}$ increase evoked by caffeine $(10 \mathrm{~mm})$ following loading of intracellular stores with a $50 \mathrm{mM} \mathrm{K}{ }^{+}$exposure. $\left[C a^{2+}\right]_{i}$ responses to caffeine were always transient regardless of the length of exposure to caffeine, and always dependent on prior loading of stores by a 50 mM $\mathrm{K}^{+}$ response (see C). $C$, Experiments using single-cell microfluorimetry showed that caffeine responses persisted in $\mathrm{Ca}^{2+}$-free external solution in five of seven cells tested. In the experiment shown, a single small response to caffeine $(10 \mathrm{~mm})$ followed the $50 \mathrm{~mm} \mathrm{~K}^{+}$response, failing to repeat without reloading of the stores. (Changes in the perfusing solution are marked by brief artifacts in this trace.) After reloading with 50 mM $\mathrm{K}^{+}$, changing to $\mathrm{a} \mathrm{Ca}^{2+}$-free external solution (buffered with $20 \mu \mathrm{M}$ BAPTA) caused a transient rise in $\left[\mathrm{Ca}^{2+}\right]_{i}$, followed by a fall in the basal $\left[\mathrm{Ca}^{2+}\right]_{i}$. Caffeine exposure after $1 \mathrm{~min}$ in $\mathrm{Ca}^{2+}$-free solution induced $\mathrm{Ca}^{2+}$ mobilization equivalent in size to that detected in $2 \mathrm{mM} \mathrm{Ca}^{2+}$ solution. The caffeine responses both in $2 \mathrm{mM} \mathrm{Ca}^{2+}$ and in $\mathrm{Ca}^{2+}$-free external solutions were repeatable only following reloading of stores. $D$, Caffeine responses were abolished by ryanodine $(10 \mu \mathrm{M})$ in a "use-dependent" fashion. In the series of experiments shown, caffeine (10 mM) responses repeated three times without substantial decrement, with $50 \mathrm{mM} \mathrm{K} \mathrm{K}^{+}$reloading of stores prior to each caffeine exposure. Following ryanodine treatment, however, subsequent caffeine responses were diminished and were abolished by the third trial. Consistent with its high-affinity binding, ryanodine's elimination of $\mathrm{Ca}^{2+}$ mobilization by caffeine persisted for at least three subsequent caffeine exposures, following a 25 min washout period. These fluorimetric imaging experiments were performed successively in the same cell separated by 20-30 min periods. Ryanodine abolished caffeine responses in all cells tested $(n=8)$. 


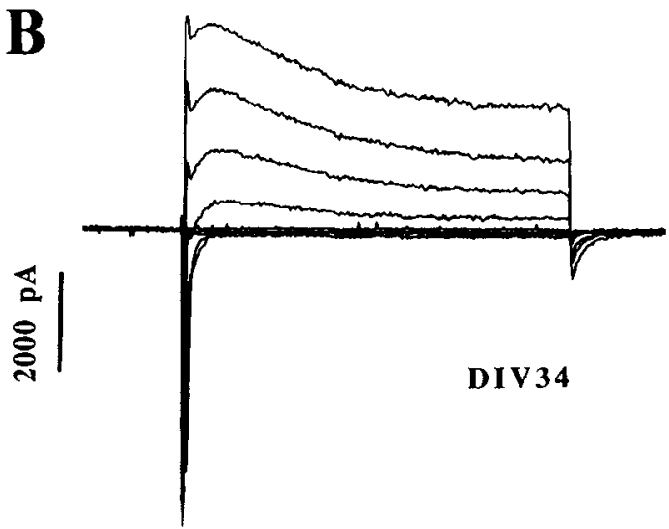

$100 \mathrm{~ms}$

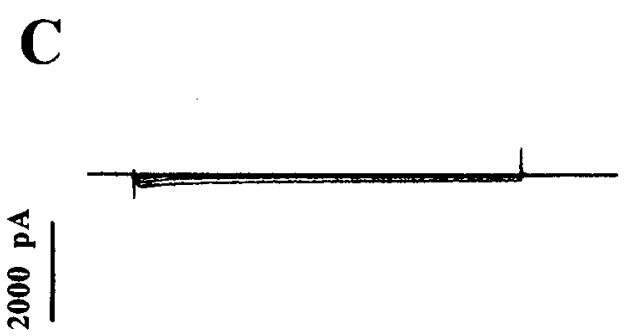

DIV3

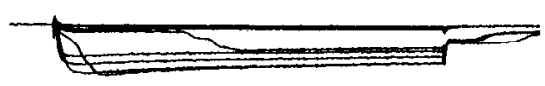

DIV 15

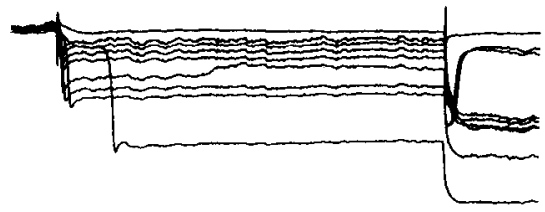

DIV36

Figure 8. Membrane currents. $A$, The neurons in the E16 cultures developed $\mathrm{Na}^{+}$currents from the earliest days in culture, as seen in a DIV 2 neuron (intracellular: $\mathrm{CsCl}, 10 \mathrm{~mm}$ EGTA; extracellular: $2 \mathrm{~mm} \mathrm{Ca}{ }^{2+} / 140 \mathrm{~mm} \mathrm{Na}^{+} / 5 \mathrm{~mm} \mathrm{~K} \mathrm{~K}^{+}$buffer). $B$, As cells matured, large outward $\mathrm{K}$ ' currents became evident as well, with outward rectification and inactivating and steady components. Here a series of current traces is shown, generated by depolarizing steps from a holding potential of $-80 \mathrm{mV}$ to test potentials of $-70 \mathrm{mV}$ up to $+40 \mathrm{mV}$ by $10 \mathrm{mV}$ steps (intracellular: $\mathrm{K}^{+}$-acetate, 10 mM EGIA; extracellular: $2 \mathrm{~mm} \mathrm{Ca} \mathrm{a}^{2+} / 140 \mathrm{~mm} \mathrm{Na} / 5 \mathrm{~mm} \mathrm{~K}{ }^{+}$buffer). $C$, Voltage-gated $\mathrm{Ca}^{2+}$ currents were initially quite small in cells of a few days age in culture, as seen in this $D I V 3$ neuron. With time, the $I_{\mathrm{Ca}}$ grew larger, as seen in this $D I V 15$ cell, but problems with the voltage clamping of the cells appeared, manifested by delayed activation and deactivation of the channels with the voltage steps, and stepwise activation of currents indicating the depolarization reaching different compartments asynchronously. In still older cells, these space-clamping problems became severe, as in this $D I V 36$ cell, and accurate measurement of the magnitudes of the total $I_{\mathrm{Ca}}$ was impossible, with some cells manifesting large currents and, in others, the $I_{\mathrm{Ca}}$ appearing small or unmeasurable (intracellular solution: $\mathrm{CsCl}, 10 \mathrm{~mm}$ EGTA; extracellular solution containing $140 \mathrm{~mm}$ TEA Cl and $2 \mathrm{mM} \mathrm{Ca}^{2+}$ ).

responses were repeatable provided that stores were reloaded by a $50 \mathrm{mM} \mathrm{K}{ }^{+}$-induced $\left[\mathrm{Ca}^{2+}\right]_{i}$ elevation prior to repeated caffeine exposures. However, repeat responses were completely dependent on reloading (Fig. 7C). Responses to caffeine persisted undiminished in size up to $6 \mathrm{~min}$ in $2 \mathrm{mM} \mathrm{Ca}^{2+}$ solution after reloading of stores. In five of seven cells, responses could also be demonstrated in the absence of external $\mathrm{Ca}^{2+}$ (Fig. 7C). The stores seemed to be quite labile in $\mathrm{Ca}^{2+}$-free solution, however, and progressively decreased in size over the first $2 \mathrm{~min}$ in $\mathrm{Ca}^{2+}$-free solution; they were absent after $3 \mathrm{~min}$ (not shown). Ryanodine ( $10 \mu \mathrm{M})$ exposure during caffeine treatment abolished repeated $\mathrm{Ca}^{2+}$ mobilization in a use-dependent fashion (Fig. $7 D$ ). The response to the first caffeine exposure in ryanodine was 98 $\pm 9 \%$ of the control response $(n=5)$, but the second caffeine response in ryanodine fell to $20 \pm 11 \%$ of control $(n=4)$, and there was no response to the third application of caffeine ( $n=$ 4). After establishment of the ryanodine effect, it was slow to wash out, preventing caffeine effects for up to $25 \mathrm{~min}$ after exposure (Fig. $7 D$ ). These results are consistent with ryanodine's putative mechanism of action, which involves high-affinity binding to the $\mathrm{Ca}^{2+}$ release channel in its open state. Under such circumstances caffeine-sensitive stores would be unable to reload.

\section{Electrophysiology}

The cerebellar neurons expressed voltage-activated membrane conductances from their earliest days in culture throughout their survival. A rapidly inactivating TTX-sensitive $\mathrm{Na}^{+}$conductance was seen in all neurons from 2 DIV onward ( $n=31$ ) (Fig. $8 A$ ). No noninactivating $\mathrm{Na}^{+}$currents were observed. Several different outwardly rectifying outward currents were seen $(n=11)$, representing both inactivating and noninactivating $\mathrm{K}^{+}$conductances (Fig. $8 B$ ), as well as $\mathrm{Ca}^{2+}$-activated $\mathrm{K}^{+}$conductances where the net outward current was diminished by blockers of $\mathrm{Ca}^{2+}$ currents (not shown). Such conductances have all been previously described in Purkinje neurons (Hirano and Ohmori, 1986; Gahwiler and Llano, 1989; Gruol et al., 1989, 1991; Hirano and Hagiwara, 1989).

$\mathrm{Ca}^{2+}$ currents $\left(I_{\mathrm{Ca}}\right)$ were also examined in these cells (Fig. $8 \mathrm{C}$ ) $(n=30)$. The $I_{\mathrm{Ca}}$ was very small or absent in neurons during the first week in culture $(n=7)$. The $I_{\mathrm{Ca}}$ grew to substantial magnitude during the second and third weeks of culture $(n=$ 
A

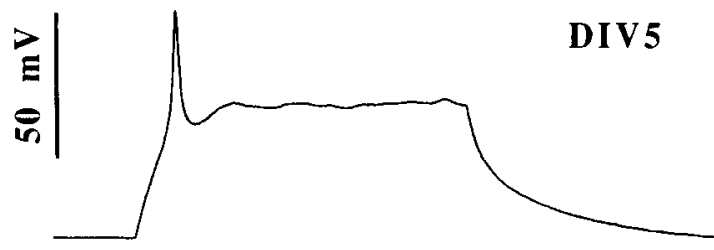

100

pA

B

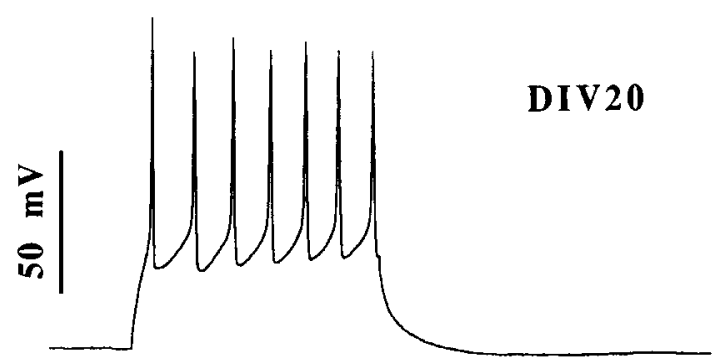

300

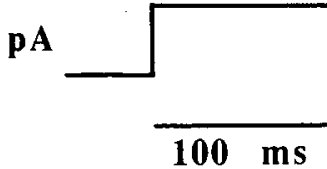

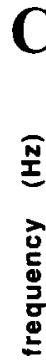

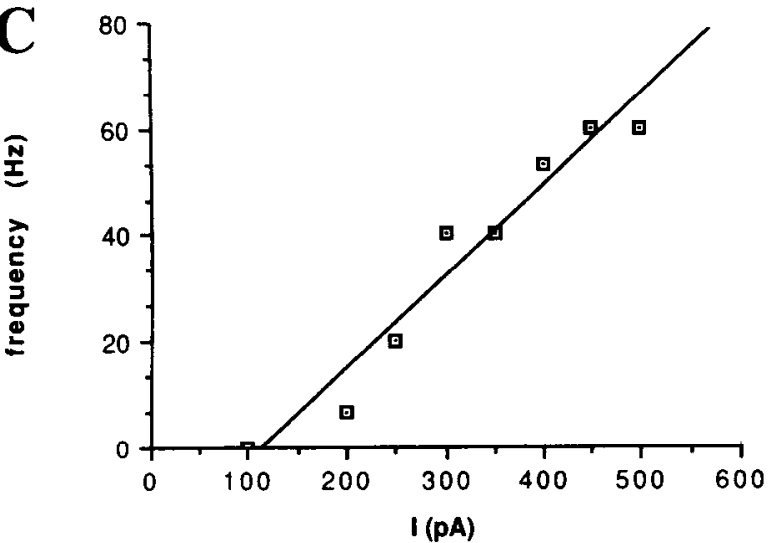

Figure 9. Evoked APs. In the current-clamp mode, the membrane responses to depolarizing current steps were examined. $A$, From the earliest days in culture, stimulated single APs were seen, as in this $D I V$ 5 cell. $B$, By the end of 1 week in culture, the neurons began to develop the capacity to fire repetitive regular APs in response to small depolarizing current injections as seen here in a $D I V 20$ cell. $C$, The firing frequency increased linearly with the magnitude of the injected current in any particular cell (intracellular: $\mathrm{K}^{+}$-acetate, $10 \mathrm{mM}$ EGTA; extracellular: $2 \mathrm{~mm} \mathrm{Ca}{ }^{2+}, 140 \mathrm{~mm} \mathrm{Na}{ }^{+}$).

20), but increasing difficulties maintaining good space clamping of the cells resulted as greater dendritic branching developed. In more maturc cells, the $I_{\mathrm{Ca}}$ values were often found to be small again or were clearly partly localized to poorly clamped regions of the cells, as evidenced by their all-or-nothing stepwise appearance during the depolarizing voltage steps and associated large tail currents (Fig. $8 C)(n=3)$. Such findings suggest that in older cells some $\mathrm{Ca}^{2+}$ channels are localized in dendritic areas, where space clamping is poor (Llinas and Sugimori, 1980a,b; Tank et al., 1988). The $I_{\mathrm{Ca}}$ could be completely blocked by 200 $\mu \mathrm{M} \mathrm{Cd}^{2+}(n=4)$.
A

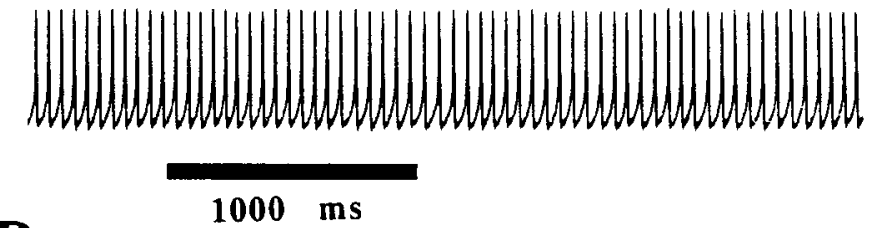

$\mathbf{B}$

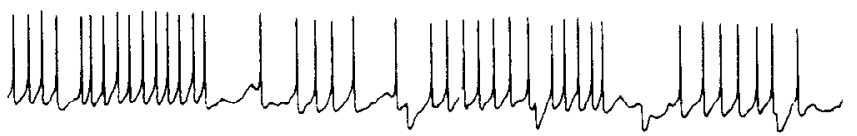

$1000 \mathrm{~ms}$

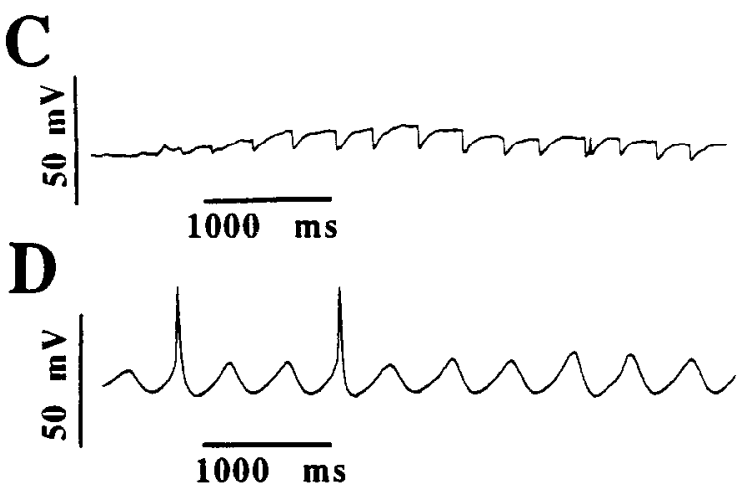

Figure 10. Spontaneous APs. Neurons of older than 2 weeks in culture were frequently found to be firing spontaneous APs in a regular pacemaker-like pattern. Such APs were TTX sensitive but insensitive to bicuculline $(20 \mu \mathrm{M})$ or CNQX $(10 \mu \mathrm{M})$. The firing frequency increased with depolarization. $A, \mathrm{~A}$ spontaneous firing pattern in the presence of bicuculline $(20 \mu \mathrm{M})$ is shown. $B$, In some cells, such as the one shown, hyperpolarizing potentials intermittently interfered with the regular firing pattern. When APs were blocked by hyperpolarization in such cells, these potentials were clearly seen to be IPSPs $(C)$ and were found to be sensitive to bicuculline. $D$. In occasional cells, a sinusoidal smooth oscillation of the membrane potential intermittently generated APs. Intracellular solutions used $\mathrm{K}^{+}$-gluconate, $0.1 \mathrm{mM}$ EGTA $(A)$, or $\mathrm{K}^{+}$acetate, 10 mм EGTA $(B-D)$; cell ages: DIV $23(A, B)$, DIV $37(C)$, DIV $40(D)$.

Current-clamp recordings were also performed $(n=70)$. From the start of the culture, neurons were able to fire single APs (Fig. $9 A$ ). At the end of 1 week in culture, neurons began to develop the capacity to fire repetitive regular APs in response to current injection (Fig. 9B). These APs were blocked by TTX $(1 \mu \mathrm{M})$, but not by $\mathrm{Ni}^{2+}(500 \mu \mathrm{M})$ or $\mathrm{Cd}^{2+}(200 \mu \mathrm{M})$. The firing frequency increased linearly with the magnitude of the injected current in any particular cell (Fig. 9C), as has been described in Purkinje cells in cerebellar slice preparations (Kapoor et al., 1988). In older cultures, essentially all of neurons expressed the capacity for firing repetitive $\mathrm{Na}^{+}$-dependent APs ( 38 of 39 cells tested of greater than 1 week of age). In the presence of TEA ( $5 \mathrm{~mm}$ ), the APs were broadened (see below and Fig. 12). With the addition of $\mathrm{Ni}^{2+}$ or $\mathrm{Cd}^{2+}$ as well as TEA, the APs returned to their narrow $\mathrm{Na}^{+}$spike shape. In some cells, pure $\mathrm{Ca}^{2+} \mathrm{APs}$ could be evoked with large depolarizing current injections in the presence of TTX and TEA (not shown).

As the cultures grew older, the networks of processes grew dense and many cell-cell contacts, with synapse formation, re- 

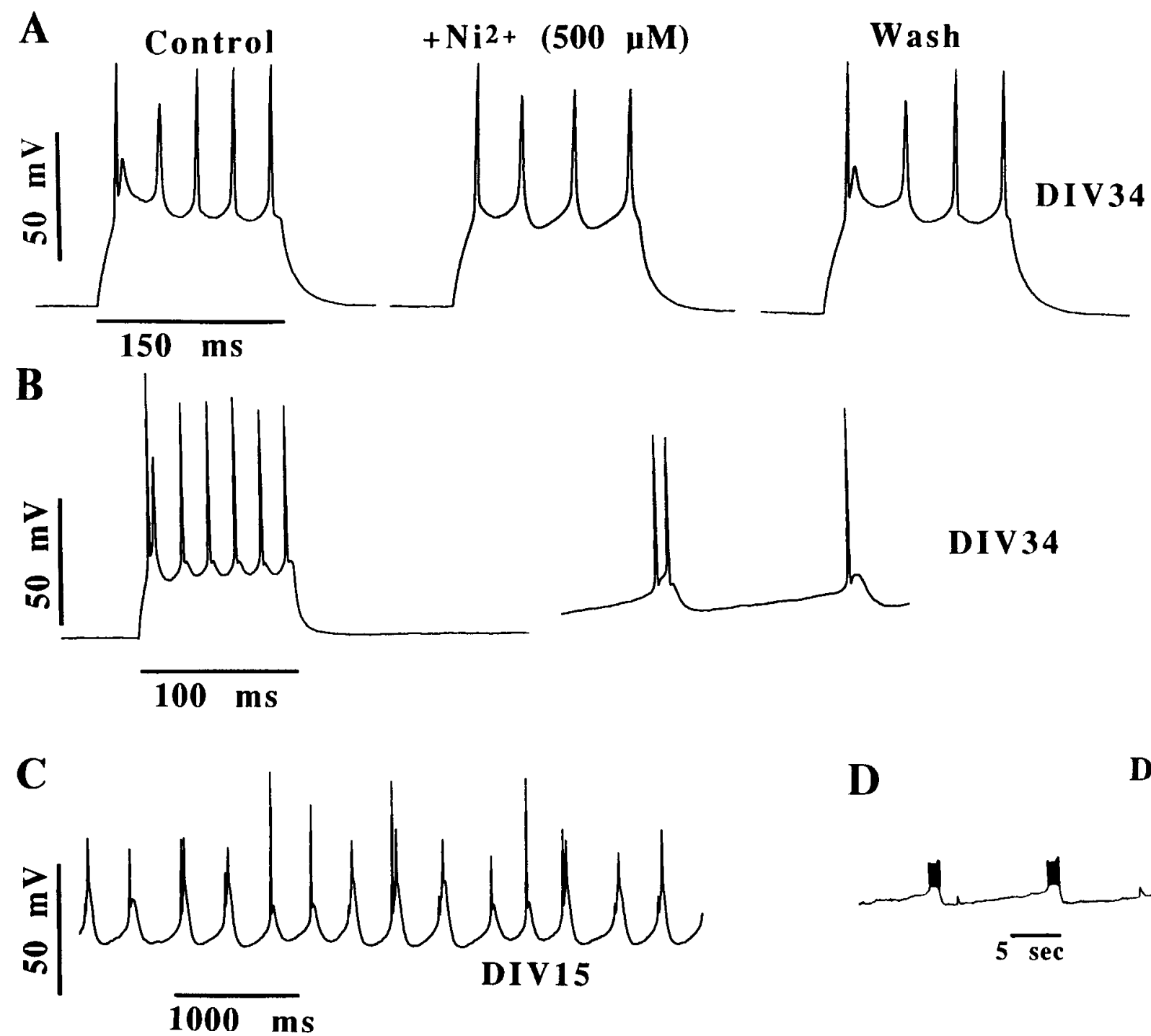

D DIV28

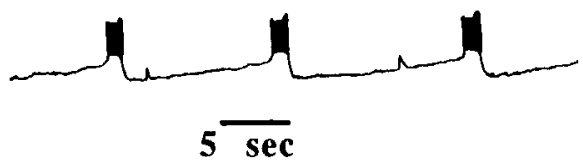

Figure 11. Bursting activity. A, Mixed spikes with distinct $\mathrm{Ca}^{2+}$ and $\mathrm{Na}^{+}$portions were seen in some older cells. Most often, these consisted of a $\mathrm{Ca}^{2+}$-dependent afterdepolarization following an evoked $\mathrm{Na}^{+}$spike, which could be blocked by the addition of $\mathrm{Ni}^{2+}(500 \mu \mathrm{M}) . B$, Such afterdepolarizations usually only followed the first AP in a train, but at times the mixed spikes were repetitive. Picrotoxin (50 $\mu \mathrm{M})$ and CNQX (10 $\mu \mathrm{M}$ ) present in the second trace of $(B)$ failed to block the mixed spikes. Spontaneously generated mixed spikes or bursts of APs were also seen, with single, double, or multiple fast spikes firing out of a slower depolarization $(B$ and $C$ ). (A slow sampling rate of $1 \mathrm{kHz}$ limits the resolution of individual spikes in $C$.) $D$, In addition to individual mixed APs, regular repetitive bursting activity could be seen, with bursts of rapid repetitive fast APs separated by long-lasting interburst hyperpolarizations (intracellular solutions: $\mathrm{K}^{+}$-acetate, $10 \mathrm{~mm}$ EGTA).

sulted. In older cultures, bicuculline-sensitive IPSPs could usually be observed, sometimes in regular trains, indicating spontaneous pacemaker-like firing in the unperturbed presynaptic GABAergic cell (see Fig. 10C). At times, bicuculline-sensitive IPSPs immediately followed each evoked AP, indicating inhibitory autapses of the stimulated cell upon itself. On rare occasions, we observed low-voltage synaptic noise or irregular EPSPlike depolarizations that werc blocked by CNQX $(10 \mu \mathrm{M})$, indicating rare excitatory glutamatergic synapses in the cultures.

Occasionally during the second week in culture and frequently thereafter, neurons were found to be spontaneously firing APs (39 of 70 neurons; $56 \%$ ). Most often the pattern was one of regular, pacemaker-like firing of uniform APs, with a frequency increasing with depolarization (Fig. 10A). These spontaneous APs were uniformly blocked by TTX $(1 \mu \mathrm{M})$ or by hyperpolarization of the cell. $\mathrm{Ca}^{2+}$ channel blockade with $\mathrm{Ni}^{2+}(500 \mu \mathrm{M})$ or
$\mathrm{Cd}^{2+}(200 \mu \mathrm{M})$ was ineffective in blocking spontaneous firing. Synaptic blockade with bicuculline $(20 \mu \mathrm{M})$ or picrotoxin $(50$ $\mu \mathrm{M})$ and CNQX $(10 \mu \mathrm{M})$ did not block such spontaneous APs, so that the generation of the spontaneous firing was generally endogenous and not dependent upon synaptic input. Endogenous AP generation has been previously described in slices (Llinas and Sugimori, 1980b) and in cell culture (Gruol and Franklin, 1987). At times, hypcrpolarizing potentials were superimposed on trains of APs, altering their regular firing patterns (Fig. 10B); when APs were blocked by hyperpolarization in such cells, regular IPSP firing could be clearly seen (Fig. 10C). In occasional cells, a sinusoidal smooth oscillation of the membrane potential was observed, only intermittently depolarizing sufficiently to generate an AP, again indicating the endogenous generation of oscillatory behavior in these neurons (Fig. 10D).

One of the most characteristic properties of Purkinje cell elec- 
trophysiology is the generation of slow dendritic $\mathrm{Ca}^{2+}$-dependent APs with superimposed fast somatic $\mathrm{Na}^{+}$spikes (Llinas and Sugimori, $1980 \mathrm{a}, \mathrm{b})$. In the older cultured neurons, mixed APs with separate $\mathrm{Na}^{+}$- and $\mathrm{Ca}^{2+}$-dependent portions were sometimes seen $(n=13)$. Most often, this consisted of a $\mathrm{Ca}^{2+}$-dependent afterdepolarization following a stimulated $\mathrm{Na}^{+}$spike (Fig. 11 A). Such afterdepolarizations usually only followed the first AP in an evoked train, but at times the mixed spikes were repetitive, and sometimes could be seen in spontaneous spikes as well. They were not blocked by CNQX $(10 \mu \mathrm{M})$ or picrotoxin $(50 \mu \mathrm{M})$ (Fig. $11 B$ ). Spontaneously generated complex spikes were also seen, with single, double, or multiple fast spikes firing out of a slower depolarization (Fig. $11 \mathrm{C}$ ), and sometimes a quite regular pattern of bursting activity could be seen, with bursts of rapid repetitive fast APs separated by long-lasting interburst hyperpolarizations (Fig. $11 D$ ) ( $n=9$ bursting neurons observed). The progression of development of electrophysiological properties from single spikes to repetitive firing to spontaneous firing to complex firing patterns is similar to that described in cultured Purkinje neurons by Gruol and Franklin (1987).

With current-clamp and simultaneous fura-2 $\left[\mathrm{Ca}^{2+}\right]_{i}$ microfluorimetric recording, the effect of activity on the somatic $\left[\mathrm{Ca}^{2+}\right]_{i}$ could be observed in these neurons. When trains of APs were evoked with depolarizing current pulses, the somatic transient $\left[\mathrm{Ca}^{2+}\right]_{i}$ increases generated were generally small or undetectable despite the rapid firing of many somatic APs (Fig. 12A). Similarly, when trains of spontaneous APs occurred, the somatic $\left[\mathrm{Ca}^{2+}\right]_{i}$ remained rather low, although moderate increases in $\left[\mathrm{Ca}^{2+}\right]_{i}$ could sometimes be observed after bursts of APs. However, when the APs were broadened by application of $5 \mathrm{~mm}$ TEA extracellularly, substantial $\left[\mathrm{Ca}^{2+}\right]_{i}$ transients were generated in the cell soma by evoked or spontaneous APs (Fig. 12A,B). These effects of TEA on both the spontaneous APs and on evoked responses in $\left[\mathrm{Ca}^{2+}\right]_{i}$ were quantitatively examined in four cells subjected to $800 \mathrm{msec}$ depolarizing injected current pulses (see Fig. 12A). In these cells, the basal $\left[\mathrm{Ca}^{2+}\right]_{i}$ was $159 \pm 17 \mathrm{~nm}$ (mean \pm SEM) and the peak increase in response to the evoked APs was $229 \pm 35 \mathrm{nM}$, producing a mean evoked change in $\left[\mathrm{Ca}^{2+}\right]_{i}$ of $69 \pm 23 \mathrm{~nm}$. In the presence of TEA ( $5 \mathrm{~mm}$ ), the basal $\left[\mathrm{Ca}^{2+}\right]_{i}$ increased to $368 \pm 89 \mathrm{nM}$, presumably due to the broadening of spontaneous APs. The peak $\left[\mathrm{Ca}^{2+}\right]_{i}$ following the evoked APs was $695 \pm 134 \mathrm{nM}$, resulting in a larger mean evoked change in $\left[\mathrm{Ca}^{2+}\right]_{i}$ of $326 \pm 85 \mathrm{nM}$. At times, steps in $\left[\mathrm{Ca}^{2+}\right]_{i}$ could be observed with each TEA-broadened AP. The $\left[\mathrm{Ca}^{2+}\right]_{i}$ responses to each of these broad APs were rapid (begining within a few

Figure 12. Somatic $\left[\mathrm{Ca}^{2+}\right]$ changes associated with APs. Simultaneous current-clamp and $\left[\mathrm{Ca}^{2+}\right]_{i}$ recordings from single cerebellar Purkinje neurons in culture illustrate the effect of TEA $(5 \mathrm{mM})$ on spontaneous and evoked APs. A, APs were evoked with $180 \mathrm{pA}$ current injections for $800 \mathrm{msec}$. Successive sweeps are shown (40 sec intervals between sweeps), except for the bottom sweep, which is $2 \mathrm{~min}$ after washout of the TEA. Initially, neither the evoked nor the spontaneous APs generated a measurable change in $\left[\mathrm{Ca}^{2+}\right]_{i}$. As TEA washed in, it broadened the spontaneous APs and produced a large $\mathrm{Ca}^{2+}$ plateau depolarization during the injected current pulse, causing significant increases in the somatic $\left[\mathrm{Ca}^{2+}\right]_{i}$ step that accompanied each AP. Spontaneous firing came to a halt. Following washout of the TEA, the narrow evoked spikes again produced no changes in somatic $\left[\mathrm{Ca}^{2+}\right]_{i} . B$, In another cell, evoked and spontaneous APs, broadened by TEA, are each associated with a jump in the somatic $\left[\mathrm{Ca}^{2+}\right]_{i}$ (E16 DIV 23 cells; intracellular: $\mathrm{K}^{+}$-gluconate; extracellular: $2 \mathrm{~mm} \mathrm{Ca}^{2+}, 140 \mathrm{~mm} \mathrm{Na}{ }^{+}$.
A
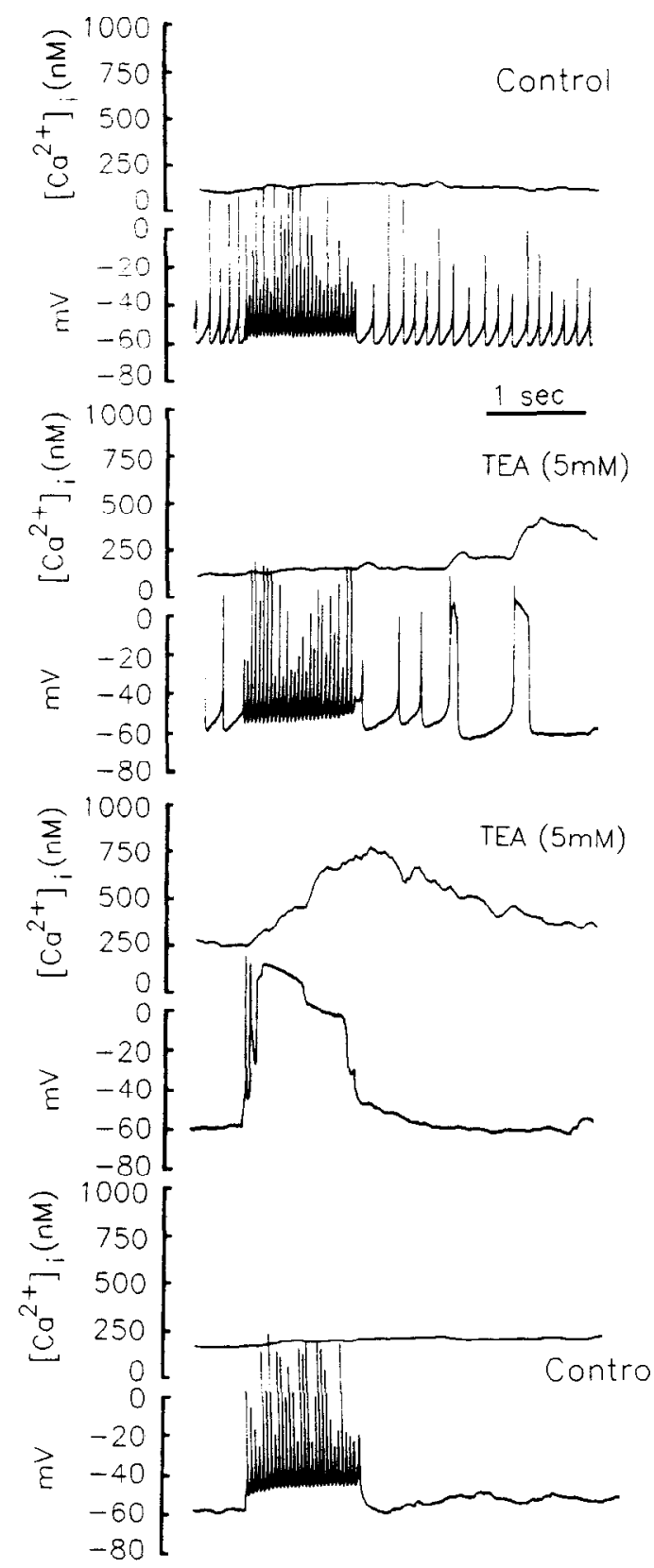

B

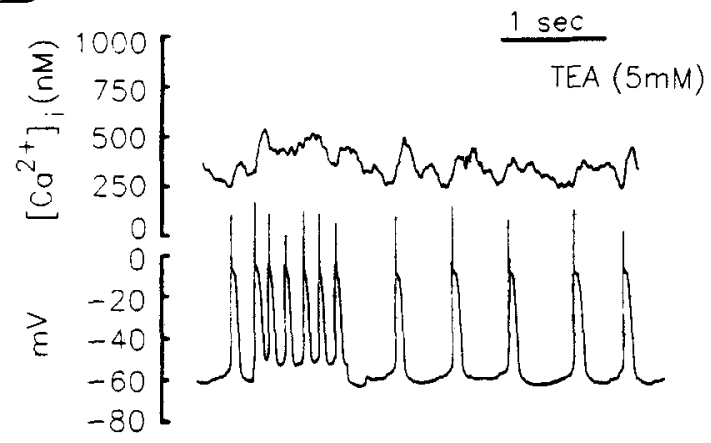




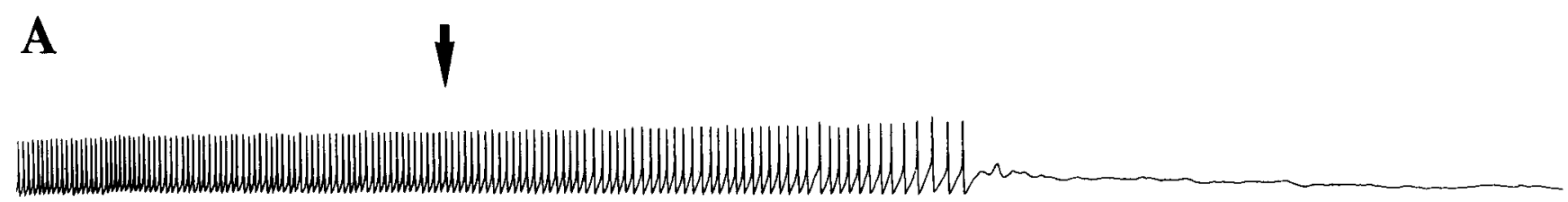

1 sec
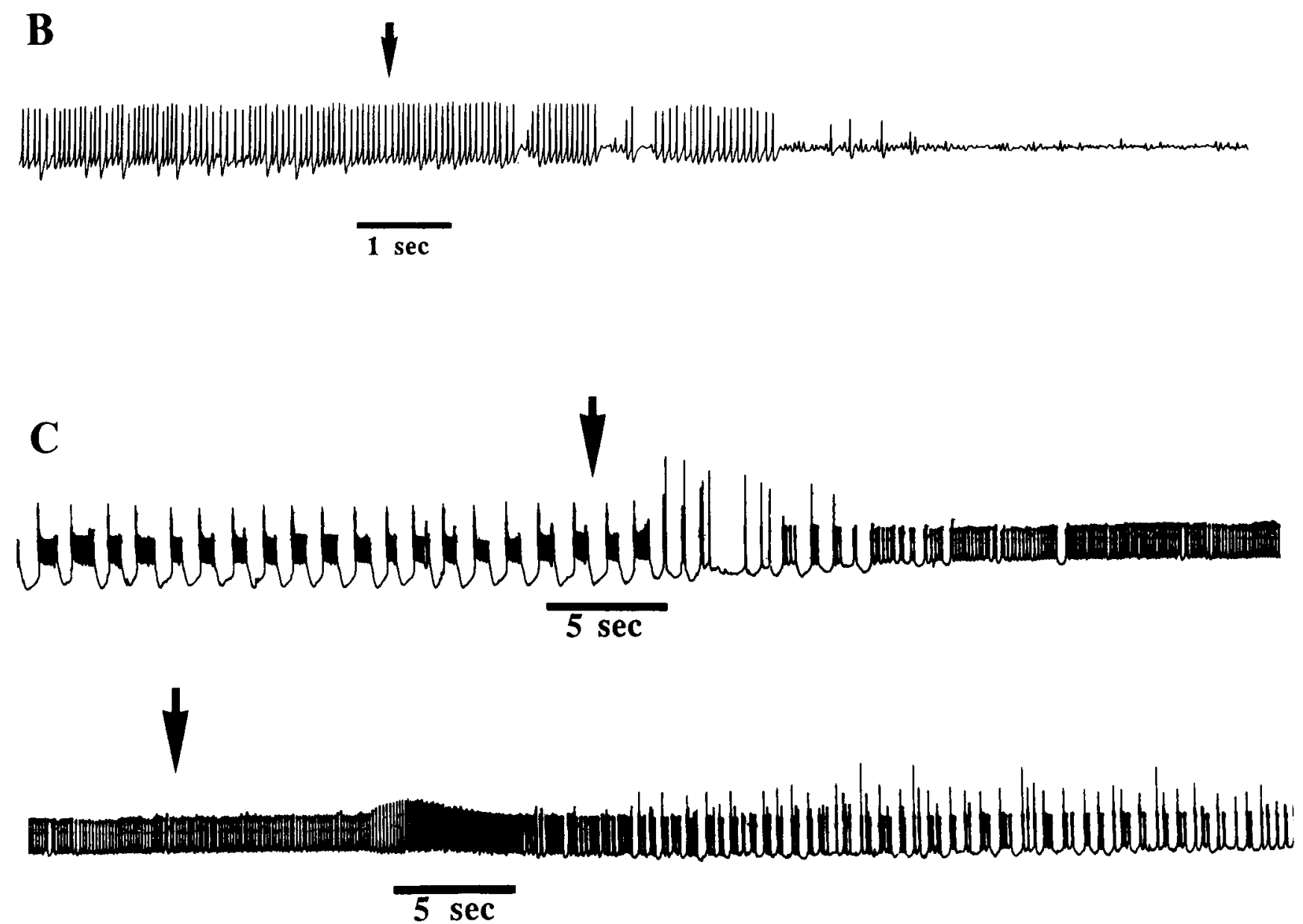

Figure 13. Caffeine effects on spontaneous firing. $A$, In this chart recording, the effect of caffeine (10 mm) on the spontaneous regular AP firing pattern of a current-clamped neuron (DIV 23) is shown. As caffeine washed in (arrow), the rate of AP firing slowed and then ceased; it resumed later following caffeine washout (not shown). B, In another DIV 23 cell, intermittent deep hyperpolarizations followed some APs. Caffeine exposure (arrow) was associated with elimination of these deep hyperpolarizations and then with cessation of AP firing. $C$, In a cell that manifested spontaneous bursting activity, caffeine reversibly converted the activity to a regular firing pattern. In these traces, caffeine (10 mM) was applied at the time marked by the first arrow and removed at the second arrow (intracellular: $A$, $\mathrm{K}^{+}$-gluconate, $0.1 \mathrm{mM}$ EGTA; $B, \mathrm{~K}^{+}-$acetate, $0.1 \mathrm{mM}$ EGTA; $C$, $\mathrm{K}^{+}$gluconate; extracellular: $2 \mathrm{mM} \mathrm{Ca}^{2+}, 140 \mathrm{mM} \mathrm{Na}{ }^{+}$; marking of the onset of caffeine exposure is approximate).

milliseconds), indicating a local influx of $\mathrm{Ca}^{2+}$ rather than diffusion to the soma from distant cell processes. Such observations suggest that although little somatic $\left[\mathrm{Ca}^{2+}\right]_{i}$ increase may be produced by normal narrow somatic spikes, there are local $\mathrm{Ca}^{2+}$ conductances sufficient to produce substantial increases in somatic $\left[\mathrm{Ca}^{2+}\right]_{i}$ if repolarization is blocked by TEA.

\section{Electrophysiological effects of caffeine}

In order to investigate the involvement of intracellular $\mathrm{Ca}^{2+}$ stores in Purkinje cell physiology, we examined the effects of caffeine on neurons under current-clamp conditions. Recordings were made both alone and with simultaneous $\left[\mathrm{Ca}^{2+}\right]$, measure- 
ment. Large neurons were selected for recording, consistent with the morphology of the calbindin-positive cells observed in staining. The effects of caffeine (10 mM) on both evoked and spontaneous activity were examined. Bicuculline $(20 \mu \mathrm{M})$ or picrotoxin $(50 \mu \mathrm{M})$ were routinely used in the recording medium to avoid nonspccific intcractions of caffeine with synaptic activity.

Spontaneously generated activity was frequently altered by caffeine. When applied to cells firing regular spontaneous APs, caffeine $(10 \mathrm{~mm})$ slowed to a halt the regular AP firing pattern in four of six such cells, with resumption of AP firing upon caffeine washout in three cells. Figure $13 \mathrm{~A}$ shows a representative recording, in which the regular AP firing first slowed in frequency and then stopped altogether after application of caffeine. Although a slight hyperpolarization of the membrane potential was seen in some cells, as in Figure $13 \mathrm{~A}$, no consistent change in the membrane potential accompanied caffeine's effect. The cell shown in Figure $13 B$ exhibited intermittent deep hyperpolarizations that synchronously followed some of the APs despite the presence of bicuculline $(20 \mu \mathrm{M})$. These hyperpolarizations seemed to be first inhibited by caffeine prior to cessation of the spontaneous firing. Similar intermittent hyperpolarizations were seen in two other cells. Of the four cells firing regular spontaneous APs that responded to caffeine, two were studied with simultaneous $\left[\mathrm{Ca}^{2+}\right]_{i}$ recording (recorded for $4 \mathrm{sec}$ sweeps once every $20 \mathrm{sec}$ ). Neither of these cells showed caffeine-induced changes in the somatic $\left[\mathrm{Ca}^{2+}\right]_{i}$ using this technique. In addition. to these regularly firing cells, two neurons firing in spontaneous bursting patterns were tested with applications of caffeine. In both of these cells, exposure to caffeine was accompanied by an increase in the basal $\left[\mathrm{Ca}^{2+}\right]_{i}$ and a transition from the bursting activity to a pacemaker-like pattern of regular slower firing of APs (Fig. 13C). Thus, in the majority (six of eight) of cells exhibiting spontaneous activity, caffeine exposure altered the pattern of that activity, tending to slow the rapidly bursting APs to a pacemaker-like regular firing patter and tending to halt the spontaneous firing in cells ready firing in a regular pattern. In some cases, these cells could also be shown to respond to caffeine with an increasc in $\left[\mathrm{Ca}^{2+}\right]_{i}$.

In contrast to spontaneous activity, evoked APs were often little altered by caffeine. In none of 14 cells examined in current clamp alone did caffeine $(10 \mathrm{~mm})$ change the repetitive AP pattern evoked by a depolarizing current pulse. Similarly, of the eight cells in which evoked APs were examined under simultaneous current clamp and $\left[\mathrm{Ca}^{2+}\right]_{i}$ recording, six showed no change in the basal $\left[\mathrm{Ca}^{2+}\right]_{i}$ in response to caffeine, and in none of these six cells did caffeine affect the evoked AP firing.

However, effects of caffeine on evoked activity could be clearly seen in the two cells in which caffeine did increase the $\left[\mathrm{Ca}^{2+}\right]_{i}$ and evoked activity was examined. These cells included one of the bursting cells described above. In these two cells, in addition to transiently elevating the basal $\left[\mathrm{Ca}^{2+}\right]_{i}$, caffeine $(10 \mathrm{mM})$ increased the size of the $\left[\mathrm{Ca}^{2+}\right]_{i}$ step produced by the evoked train of APs and induced a slow afterhyperpolarization (AHP) following the AP train (Fig. 14A). The sequential effects of caffeine and ryanodine exposures are shown in Figure $14 B$. Trace 2 shows the elevation in basal $\left[\mathrm{Ca}^{2+}\right]_{i}$, the increased $\left[\mathrm{Ca}^{2+}\right]_{i}$ step size, and the slow AHP induced by caffeine. Although the elevation in the basal $\left[\mathrm{Ca}^{2+}\right]_{i}$ was typically transient presumably due to $\mathrm{Ca}^{2+}$ release from intracellular stores, the increase in the $\left[\mathrm{Ca}^{2+}\right]_{i}$ step size persisted for the duration of caffeine exposure (Fig. 14B, trace 3) and reversed only with washout of caffeine (trace 4). Repeated exposure to caffeine again induced these reversible increases in the $\left[\mathrm{Ca}^{2+}\right]_{i}$ step size and the AHP, although the elevation of the basal $\left[\mathrm{Ca}^{2+}\right]_{i}$ failed to occur (trace 5). Ryanodine $(10 \mu \mathrm{M})$ applied to these cells had no effect alone (traces 6,7 ). However, after simultaneous caffeine and ryanodine exposure the effects of caffeine seemed to wash out less rapidly (compare traces 10 and 6 ). These observations are consistent with the elimination of a component of the $\mathrm{Ca}^{2+}$ buffering capacity of the cell soma by exposure to caffeine through the opening of the $\mathrm{Ca}^{2+}$ release channels of the internal stores. Such an effect would cause a greater increase in free $\left[\mathrm{Ca}^{2+}\right]_{i}$ to result from the same influx of $\mathrm{Ca}^{2+}$, causing greater activation of $\mathrm{Ca}^{2+}$ dependent outward currents.

\section{Discussion}

Previous studies reported by our laboratory have sought to define the various processes responsible for the influx, buffering, and removal of $\mathrm{Ca}^{2+}$ from neurons (reviewed in Miller, 1991). The interplay of these various factors produces the $\mathrm{Ca}^{2+}$ signals that are important in the regulation of various neuronal functions including transmitter release and cell excitability. We have previously demonstrated that central and peripheral neurons contain two types of $\mathrm{Ca}^{2+}$ stores that may be differentially distributed within the cell (Murphy and Miller, 1988, 1989; Thayer et al., 1988a-c). These stores can be regulated by $I P_{3}$ and caffeine, respectively, and may participate in the neuronal response to neurotransmitters and in the amplification and buffering of neuronal $\mathrm{Ca}^{2+}$ signals. Very little information is currently available on the properties of $\mathrm{Ca}^{2+}$ stores in central neurons. $\mathrm{Ca}^{2+}$ mobilization in response to $\mathrm{IP}_{3}$-generating neurotransmitters has been reported and mobilization of $\mathrm{Ca}^{2+}$ by caffeine has been noted in passing in a few instances (Murphy and Miller, 1989; Charpak et al., 1990; Glaum et al., 1990; Miller, 1991). Furthermore, the physiological roles of such stores in central neurons are also quite unclear. We have chosen to study these entities in cerebellar Purkinje cells due to the particularly high levels of $\mathrm{Ca}^{2+}$-handling components that seem to exist in these

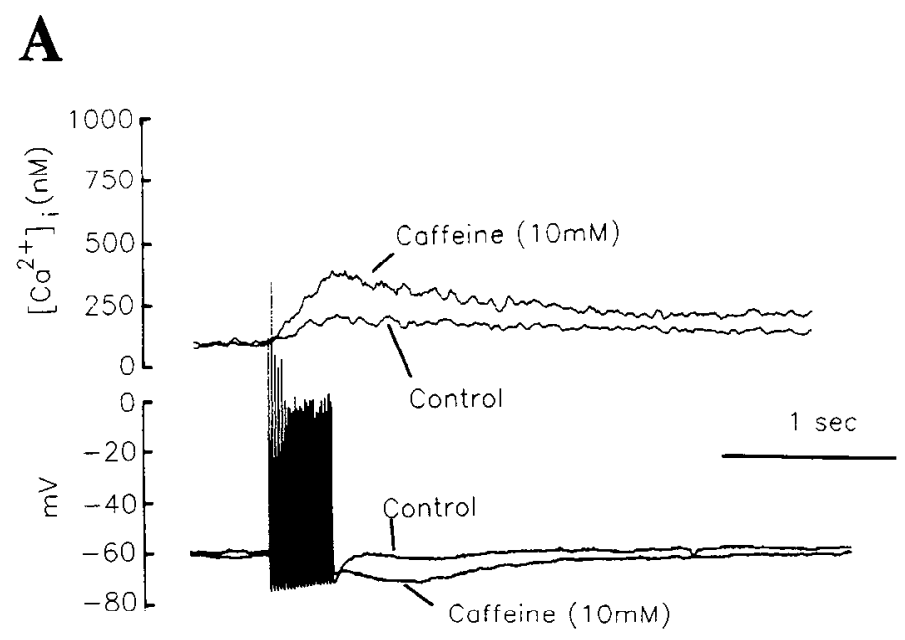

Figure 14. Caffeine effects on evoked activity. Simultaneous currentclamp and $\left[\mathrm{Ca}^{p+}\right]_{i}$ rccordings from a cultured cerebellar neuron (DIV 35) were made under whole-cell patch clamp with $100 \mu \mathrm{M}$ fura-2 pentapotassium salt in the patch pipette. APs were elicited by brief current pulses $(800 \mathrm{pA}, 4 \mathrm{msec}, 50 \mathrm{~Hz})$. A, Superimposed traces show the effects of caffeine (10 $\mathrm{mm})$ on the evoked activity. In caffeine, the induced rise in somatic $\left[\mathrm{Ca}^{2+}\right]_{i}$ was increased over control, and a slow AHP followed the evoked burst of APs. These effects persisted even in the absence of a change in the basal $\left[\mathrm{Ca}^{2+}\right]_{i}$. 
B

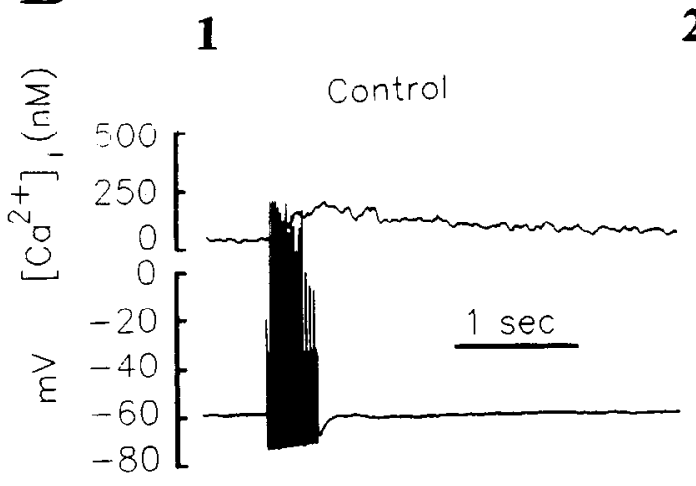

4

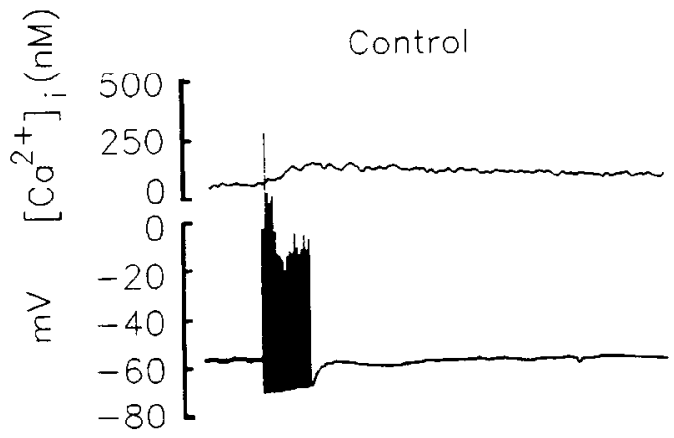

7

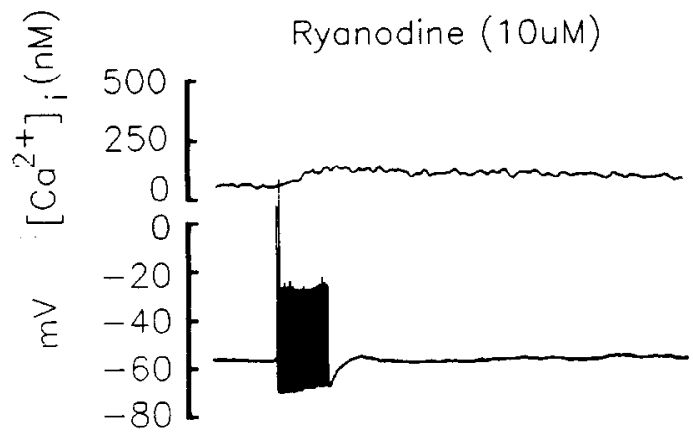

10

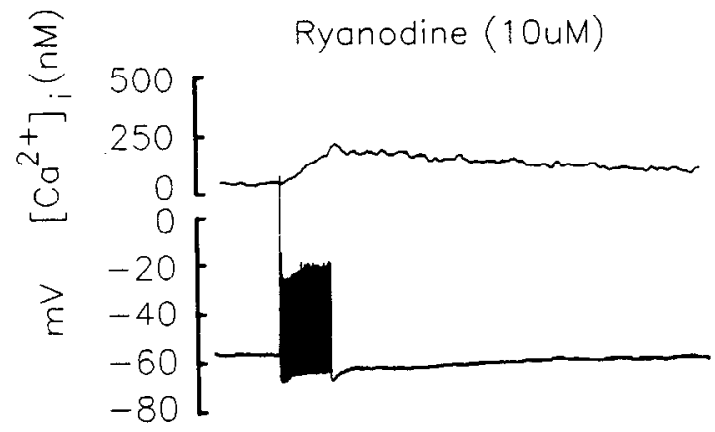

2

Caffeine (10mM)

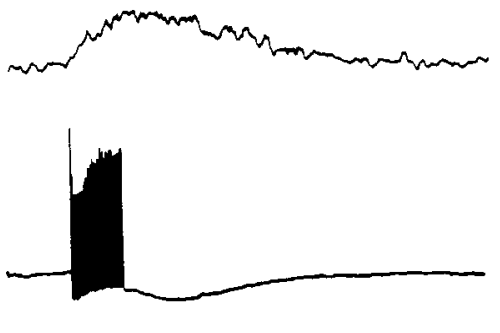

5

Caffeine (10mM)

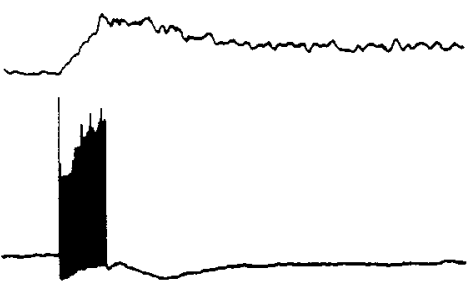

8

Rycnodine (10uM)

+ Caffeine (10mM)

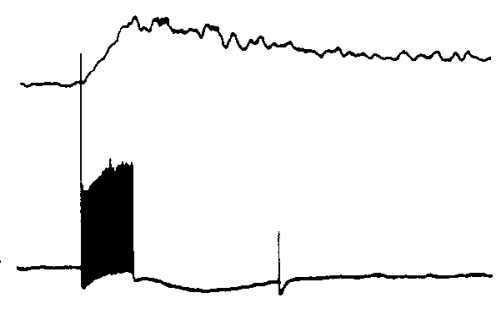

11

Control
3

Caffeine (10 mM)

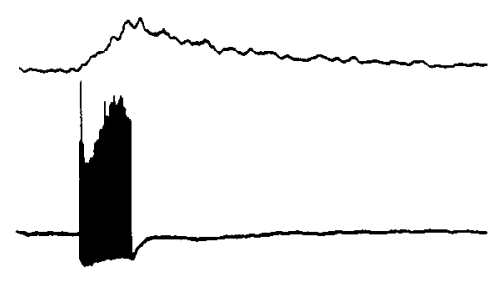

6

Control

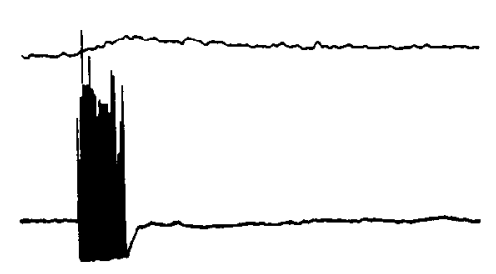

9

Ryanodine (10uM)
+ Caffeine $(10 \mathrm{mM})$

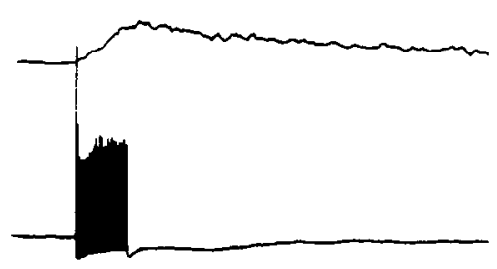

12

Caffeine $(10 \mathrm{mM})$
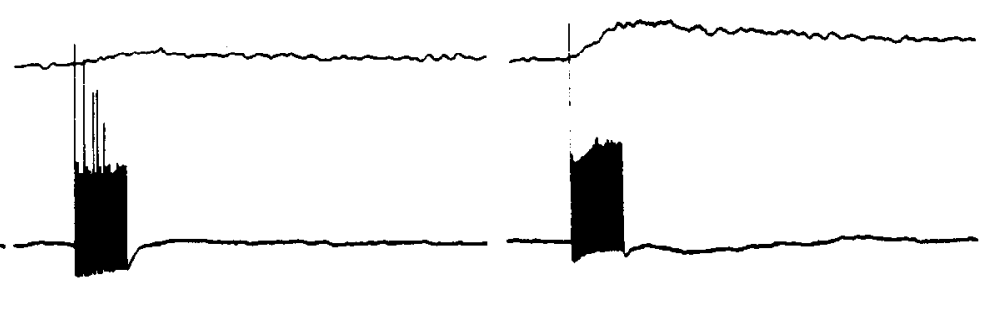

$B$. Sequential traces show the effects of perfusing the cell with caffeine and ryanodine $(10 \mu \mathrm{M})$, and the associated changes in the $\left[\mathrm{Ca}^{2+}\right]_{i}$ and the AHP that resulted. Successive sweeps are separated by $40 \mathrm{sec}$ intervals. The initial exposure to caffeine produced a rise in the basal [Ca $\left.{ }^{2+}\right]_{i}$ as well as increasing the $\left[\mathrm{Ca}^{2+}\right]_{i}$ step size associated with evoked APs and inducing the slow AHP (trace 2). Subsequent exposures to caffeine (traces 5 , 8 , 12) produced these latter effects without affecting the basal $\left[\mathrm{Ca}^{2+}\right]_{i}$. Ryanodine exposure had no effect alone (trace 7$)$; however, the effects of caffeine exposure in ryanodine did not wash out completely with the caffeine but seemed to be more persistent (compare traces 10 and 6 ) (intracellular solution: $\mathrm{K}^{+}$-gluconate, no EGTA). 
cells. For example, Purkinje cells are thought to contain extremely high levels of IP ${ }_{3}$ R (Ross et al., 1989; Satoh et al., 1990), $\mathrm{Ca}^{2+}$-binding proteins (Baimbridge et al., 1982; Celio, 1990), $\mathrm{Ca}^{2+}$ pumps (Plessers et al., 1991), and RyR (Ellisman et al., 1990), which are thought to be specific markers for caffeinesensitive $\mathrm{Ca}^{2+}$ stores. However, identification of these molecules has generally been the result of histochemical studies. The functional properties of these components and their role in Purkinje cell physiology remain to be demonstrated. Thus, we sought to produce a cell culture preparation of Purkinje cells that would help us to study these processes.

Dissociated cell culture offers several advantages over slice preparations but presents the disadvantage of uncertain cell identification, as cells may not develop with a completely normal morphology. In order to draw conclusions about a particular cell type from experiments done on cultured neurons, one must either rely on morphological criteria for cell identification, mark the cells studied specifically with fluorescent or immunocytochemical markers, or work in a culture system in which the cell population expresses a relatively pure phenotype. We have sought to follow this last approach. Previously reported cerebellar culture systems have contained relatively small percentages of Purkinje cclls (<1\%) (Weber and Schachner, 1984; Bossu ct al., 1989a). By taking cerebella from immature animals, we have produced a culture system in which about one-half of the cells can be identified as "Purkinje cells" by immunocytochemical staining for calbindin and other definitive markers. Wassef et al. (1985) also suggest that some fraction of the Purkinje cell population is calbindin negative in the developing cerebellum. Such cells may account for the observation of a minority of both $\mathrm{IP}_{3} \mathrm{R}$-positive cells and RyR-positive cells that are negative for calbindin staining. If this is the case, then the calbindin staining may give an undercount of the true number of Purkinje cells. The finding that most of the cultured neurons do not respond directly to NMDA is also consistent with a high representation of Purkinje cells in the cultures. The remainder of the neurons in these cultures are likely to incude GABAergic interneurons such as the Golgi cells, and the deep cerebellar nuclear neurons that are produced on E14 (Altman and Baycr, 1985b) arc calbindin negative (Legrand et al., 1983; but see also Enderlin et al., 1987) and are thought to be glutamatergic (Monaghan et al., 1986). More than $80 \%$ of the neurons express GABA by immunocytochemistry, putting an upper limit on the proportion of deep nuclear neurons, which do not contain GABA (Gabbott et al., 1986). We thus have produced a culture system enriched for Purkinje neurons or their cell culture equivalent by an order of magnitude over those previously described. However, because we are still gathering data from a mixed population of cultured neurons, caution must be used in ascribing any particular results specifically to the Purkinje cell subset.

Before considering the data on intracellular $\mathrm{Ca}^{2+}$ stores, several general properties of the cells are worth noting. We examined the somatic $\left[\mathrm{Ca}^{2+}\right]_{i}$ response to different glutamate receptor agonists. In the cultured cerebellar neurons, universal responsiveness to agonists of the KA/AMPA classes of receptors contrasted with lack of direct responsiveness to NMDA in the majority of cells examined. The lack of NMDA responsiveness is consistent with the findings of most investigators studying Purkinje neurons in various models (Crepel et al., 1982, 1983; Audinat et al., 1990; Perkel et al., 1990; Llano et al., 1991; but see also Garthwaite et al., 1987; Krupa and Crepel, 1990). The small indirect responses, seen even in the presence of TTX but eliminated by blockade of KA/AMPA receptors with CNQX, underscore the importance of isolating cells from synaptic interactions when testing for responses to excitatory neurotransmitters. The small CNQX-sensitive responses to NMDA that were seen indicate the activation of presynaptic cells by NMDA. The cells directly responsive to NMDA would presumably correspond to deep cerebellar nuclear neurons, which are thought to be the only excitatory neurons present in these cultures and are known to be NMDA sensitive (Audinat et al., 1990). It is interesting to note that a similar situation was recently reported by Llano et al. (1991), using the cultured cerebellar slice. These authors observed that KA directly depolarized Purkinje cells but that NMDA only produced CNQX-sensitive responses due to the activation of presynaptic neurons. The lack of sensitivity to NMDA is a very unusual phenotype. The preservation of this property in our cell culture system supports our contention that the cells we are studying are Purkinje cells.

We also examined the electrophysiological properties of these neurons. We observed early expression of $\mathrm{Na}^{+}, \mathrm{K}^{+}$, and $\mathrm{Ca}^{2+}$ channels, with evidence for localization of a portion of the $\mathrm{Ca}^{2+}$ conductances to dendritic regions in more mature neurons, consistent with reports of Sugimori and Llinas (1990) and Hockberger et al. (1989b). Indeed, it has been reported that the soma of the Purkinje cell is completely devoid of voltage-sensitive $\mathrm{Ca}^{2+}$ channels (Tank et al., 1989; Sugimori and Llinas, 1990). In our experiments, the somatic $\left[\mathrm{Ca}^{2+}\right]_{i}$ changes produced by AP firing were usually small or absent, consistent with these studies. However, TEA blockade of repolarization allowed extensive $\mathrm{Ca}^{2+}$ influx and significant increases in somatic $\left[\mathrm{Ca}^{2+}\right]$, as did long-term depolarization with high $\mathrm{K}^{+}$, indicating the presence of some $\mathrm{Ca}^{2+}$ channels in the somatic membrane (see also Ross and Werman, 1987; Ross et al., 1990; Knopfel et al., 1991; Lasser-Ross et al., 1991). Several reports of single-channel measurements in patches excised from the somatic membrane of cultured Purkinje cells (Bossu et al., 1989a,b) and others of $\mathrm{Ca}^{2+}$ currents in acutely dissociated Purkinje cells (Kaneda et al., 1990; Regan, 1991; Regan et al., 1991) support this contention. Furthermore, antisera against $\mathrm{Ca}^{2+}$ channel subunits strain the Purkinje cell soma strongly in brain slices (Ahlijanian et al., 1990). It is possible that cultured Purkinje cells may lack many of the normal developmental stimuli that come from neighboring cells and the tissue environment and that their development may not fully recapitulate the in vivo situation. Thus, it is possible that the somatic expression of $\mathrm{Ca}^{2+}$ channels in our cultures is due to the relatively undeveloped status of these cells. However, it may also be that the relative lack of measured $\left[\mathrm{Ca}^{2+}\right]_{i}$ transients in the Purkinje cell soma is due not to a complete lack of somatic $\mathrm{Ca}^{2+}$ channels as much as to the abundance of efficient $\mathrm{Ca}^{2+}$ buffering mechanisms in the large reservoir of somatic cytoplasm. This may be sufficient to maintain a low $\left[\mathrm{Ca}^{2+}\right]_{i}$ in the face of a relatively small influx of $\mathrm{Ca}^{2+}$ through the somatic membrane. Only when a continuous maximal somatic $\mathrm{Ca}^{2+}$ influx is brought about by TEA blockade of $\mathrm{K}^{+}$ channels would these buffering mechanisms be overcome so that a substantial elevation in somatic $\left[\mathrm{Ca}^{2+}\right]_{i}$ is observed. In contrast, the buffering capacity of the small cytoplasmic volume in dendritic areas would be expected to be more readily overcome particularly if there are relatively higher densities of $\mathrm{Ca}^{2+}$ channels in these areas (Sugimori and Llinas, 1990). Such a model would explain the apparently contrasting views found in the literature.

In accordance with our expectations from the literature, Purkinje cells in culture also exhibited high concentrations of various proteins involved in $\mathrm{Ca}^{2+}$ homeostatic mechanisms, such 
as the $\mathrm{Ca}^{2+}$-binding protein calbindin. We have also shown positive immunocytochemical identification of high concentrations of $\mathrm{IP}_{3} \mathrm{R}$ in these cells. However, we have not been able to demonstrate mobilization of intracellular $\mathrm{Ca}^{2+}$ by stimulation with quisqualate or $t$-ACPD, even though metabotropic glutamate receptors are known to occur in Purkinje cells (Huang et al., 1990; Mayer and Miller, 1990; Schoepp et al., 1990; Masu et al., 1991). On the other hand, there are several reports illustrating glutamate-stimulated $\mathrm{IP}_{3}$ production and $\mathrm{Ca}^{2+}$ mobilization in cultures of cerebellar granule cells (e.g., Bouchelouche et al., 1989; Irving et al., 1990) that contain only low levels of $\mathrm{IP}_{3} \mathrm{R}$ and are reported not to contain many metabotropic receptors (Masu et al., 1991). This suggests the possibility that the metabotropic receptors in Purkinje cells may be associated with actions other than $\mathrm{Ca}^{2+}$ mobilization (Charpak et al., 1990; Charpak and Gahwiler, 1991). Alternatively, it may be that the metabotropic responses are selectively localized in the dendritic regions of these cells as suggested in a recent abstract (Dreessen et al., 1991) and would not have been picked up in our measurements that concentrated on the cell soma. However, the disparity may also have a trivial explanation in that it may prove that the proper conditions for identification of $\mathrm{IP}_{3}$-mediated release of $\mathrm{Ca}^{2+}$ from intracellular stores have not yet been found. For example, the substantial $\mathrm{Ca}^{2+}$ buffering in the Purkinje cell somatic cytoplasm may mask any $\mathrm{Ca}^{3+}$ rclcase in that region.

We also found immunocytochemical evidence for RyR in about one-half of the cultured neurons that also appeared to represent the Purkinje cell population. We were able to show that a similar fraction of the neurons respond to caffeine with mobilization of intracellular $\mathrm{Ca}^{2+}$ stores. Such caffeine responses were transient and depended on prior loading of the stores via elevation of cytoplasmic $\left[\mathrm{Ca}^{2+}\right]_{i}$. Ryanodine abolished subsequent $\mathrm{Ca}^{2+}$ accumulation and release in a use-dependent fashion. This is consistent with its putative mechanism, binding to the $\mathrm{Ca}^{2+}$ release channel in its open state. The general colocalization of the RyR to neurons staining for calbindin suggests that at least the majority of cells responsive to caffeine are Purkinje cells. Considering the large numbers of RyR that seem to be localized in Purkinje cells, the caffeine-induced $\left[\mathrm{Ca}^{2+}\right]_{i}$ elevations were not particularly largc. Howcver, this may again be due to the efficient $\mathrm{Ca}^{2+}$ buffering capacity of the Purkinje cell soma discussed above.

Release of $\mathrm{Ca}^{2+}$ from intracellular stores might be expected to influence the electrophysiological activity of the cell, depending on the spatial distribution of the signal. Indeed, effects of caffeine on the activity of some neurons were observed. In these cells, removing the contribution of the caffeine-sensitive stores to the buffering of cytoplasmic $\left[\mathrm{Ca}^{2+}\right]_{i}$ (e.g., Fig. 14) by treatment with caffeine and ryanodine could be shown to increase the magnitude of the transient $\left[\mathrm{Ca}^{2+}\right]_{i}$ step induced by evoked APs, and to produce a slow AHP following the AP trains. This AHP appeared to correlate well with the increased cytoplasmic $\left[\mathrm{Ca}^{2+}\right]_{i}$ and is probably produced by $\mathrm{Ca}^{2+}$-activated outward currents (Akaike and Sadoshima, 1989). In other cells, caffeine treatment halted spontaneous repetitive firing or bursting activity, an effect that could be mediated by localized increases in $\left[\mathrm{Ca}^{2+}\right]_{i}$ at the sites of AP generation, leading to the activation of $\mathrm{K}^{+}$or $\mathrm{Cl}^{-}$currents or to the inactivation of $\mathrm{Ca}^{2+}$ currents. A nonspecific action of $10 \mathrm{~mm}$ caffeine upon the relevant ion channels cannot be ruled out (see Hughes et al., 1990), but the association of caffeine effects on spontaneous activity with measured effects on $\left[\mathrm{Ca}^{2+}\right]_{i}$ increases and buffering in some cells suggests that, at least in these cells, caffeine is acting via a specific action upon intracellular $\mathrm{Ca}^{2+}$ stores. The spontaneously occurring deep hyperpolarizations observed in Figure 13, B and $C$, eliminated after addition of caffeine, are clearly reminiscent of similar events (named spontaneous miniature outward currents) recorded in peripheral neurons, which are thought to be due to the intermittent release of $\mathrm{Ca}^{2+}$ from intracellular stores (Fujimoto et al., 1980; Mathers and Barker, 1984; Satin and Adams, 1987).

It is clear that we observed caffeine-induced $\mathrm{Ca}^{2+}$ release in a greater percentage of cells using the paradigm illustrated in Figure 7 than in patch-clamp experiments that also examined electrophysiological effects of the drug. The reason for this is not entirely clear. However, the stores do appear to be extremely labile and so may have been compromised during whole-cell recording conditions. Second, $\mathrm{Ca}^{21}$ mobilization observed in our studies has been examined at the level of the cell soma, whereas many important electrophysiological events in the Purkinje cell are generated in the dendrites (Llinas and Sugimori, 1980a,b). It may be that evoked responses to somatic current injections are relatively insensitive to release of $\mathrm{Ca}^{2+}$ from caffeine-sensitive stores, compared to physiological activity occurring in dendritic regions where the content of the $\mathrm{Ca}^{2+}$ stores relative to the restricted cytoplasmic volume may be greater. Nevertheless, it is clear that caffeine-induced $\mathrm{Ca}^{2+}$ mobilization does influence Purkinje cell activity in a considerable number of instances.

The fact that we have been able to demonstrate effects of caffeine on $\left[\mathrm{Ca}^{2+}\right]_{i}$ and Purkinje cell electrophysiology does not fully answer the question as to the normal physiological role of these stores. Clearly, they may potentially act either to release $\mathrm{Ca}^{2+}$ or to buffer it, depending on prevailing conditions, and it is not yet clear when each mode of behavior is employed. However, the existence of such entities in central neurons must be taken into account when considering the regulation of the neuronal $\mathrm{Ca}^{2+}$ signals that control many important cellular functions.

\section{References}

Ahlijanian MK, Westenbroek RE, Catterall WA (1990) Subunit structure and localization of dihydropyridine sensitive calcium channels in mammalian brain, spinal cord and retina. Neuron 4:819-832.

Akaike N, Sadoshima JI (1989) Caffeine affects four different ionic currents in the bullfrog sympathetic neurone. J Physiol (Lond) 412: $221-244$

Altman J, Bayer SA (1985a) Embryonic development of the rat cerebellum. I. Delineation of the cerebellar primordium and early cell movements. J Comp Neurol 231:1-26.

Altman J, Bayer SA (1985b) Embryonic development of the rat cerebellum. II. Translocation and regional distribution of the deep neurons. J Comp Neurol 231:27-41.

Altman J, Bayer SA (1985c) Embryonic development of the rat cerebellum. III. Regional differences in the time of origin, migration, and settling of Purkinje cells. J Comp Neurol 231:42-65.

Audinat E, Knopfel T, Gahwiler BH (1990) Responses to excitatory amino acids of Purkinje cells and neurones of the deep nuclei in cerebellar slice cultures. J Physiol (Lond) 430:297-313.

Baimbridge KG, Miller JJ, Parkes CO (1982) Calcium-binding protein distribution in the rat brain. Brain Res 239:519-525.

Bossu JL, Dupont JL, Feltz A (1989a) Calcium currents in rat cerebellar Purkinje cells maintained in culture. Neuroscience 30:605-617.

Bossu JL, Fagni L, Feltz A (1989b) Voltage-activated calcium channels in rat Purkinje cells maintained in culture. Pfluegers Arch 414:9294.

Bouchelouche P, Belhage B, Frandsen A, Drejer J, Schousboe A (1989) Glutamate receptor activation in cultured cerebellar granule cells increases free $\mathrm{Ca}^{2+}$ by mobilization of cellular $\mathrm{Ca}^{2+}$ and activation of $\mathrm{Ca}^{2+}$ influx. Exp Brain Res 76:281-291. 
Byron K, Villereal M (1989) Mitogen induced changes in individual human fibroblasts. J Biol Chem 264:18234-18239.

Celio MR (1990) Calbindin D-28k and parvalbumin in the rat nervous system. Neuroscience 35:375-475.

Charpak S, Gähwiler BH (1991) Glutamate mediates a slow synaptic response in hippocampal slice cultures. Proc R Soc Lond [Biol] 243: 221-226.

Charpak S, Gähwiler BH, Do KP, Knopfel T (1990) Potassium conductances in hippocampal neurons blocked by excitatory amino acid transmitters. Nature 347:765-767.

Crepel F, Dhanjal SS, Sears TA (1982) Effect of glutamate and related derivatives on cerebellar Purkinje cell dendrites in the rat: an in vitro study. J Physiol (Lond) 316:127-138.

Crepel F, Dupont JL, Gardette R (1983) Voltage clamp analysis of the effect of excitatory amino acids on Purkinje cell dendrites in rat cerebellar slices maintained in vitro. Brain Res 279:311-315.

Dreessen J, Kano M, Llano I, Konnerth A (1991) Glutamate induced calcium release in cerebellar Purkinje cells. Pfluegers Arch 241(S1) $\mathrm{R} 12$.

Ellisman MH, Deerinck TJ, Ouyang Y, Beck CF, Tanksley SJ, Walton PD, Airey JA, Sutko JL (1990) Identification and localization of ryanodine binding proteins in the avian central nervous system. Neuron 5:135-146.

Enderlin S, Norman AW, Celio MR (1987) Ontogeny of the calcium binding protein calbindin D-28k in the rat nervous system. Anat Embryol 177:15-28.

Fujimoto S, Yamamoto Y, Kuba K, Morita K, Kato E (1980) Calcium localization in the sympathetic ganglion of the bullfrog and effects of caffeine. Brain Res 202:21-32.

Gabbott PLA, Somogyi J, Stewart MG, Hamori J (1986) GABAimmunoreactive neurons in the rat cerebellum: a light and electron microscope study. J Comp Neurol 251:474-490.

Gahwiler BH, Llano I (1989) Sodium and potassium conductances in somatic membranes of rat Purkinje cells from organotypic cerebellar cultures. J Physiol (Lond) 417:105-122.

Garthwaite G, Yamini B Jr, Garthwaite J (1987) Selective loss of Purkinje and granule cell responsiveness to $N$-methyl-D-aspartate in rat cerebellum during development. Dev Brain Kes 36:288-292.

Glaum SR, Scholz WK, Miller RJ (1990) Acute and longterm glutamate mediated regulation of $\left[\mathrm{Ca}^{2+}\right]_{i}$ in rat hippocampal pyramidal neurons in vitro. J Pharmacol Exp Ther 253:1293-1302.

Gruol DL, Crimi CP (1988) Morphological and physiological properties of rat cerebellar neurons in mature and developing cultures Dev Brain Res 41:135-146.

Gruol DL, Franklin CL (1987) Morphological and physiological differentiation of Purkinje neurons in cultures of rat cerebellum. J Neurosci 7:1271-1293.

Gruol DL, Dionne VE, Yool AJ (1989) Multiple voltage-sensitive $\mathrm{K}^{+}$ channels regulate dendritic excilability in cerebellar Purkinje neurons. Neurosci Lett 97:97-102.

Gruol DL, Jacquin T, Yool AJ (1991) Single channel $\mathrm{K}^{+}$currents recorded from the somatic and dendritic regions of cerebellar Purkinje neurons in culture. J Neurosci 11:1002-1016.

Hamill O, Marty A, Neher E, Sakmann B, Sigworth F (1981) Improved patch clamp technique for high resolution current recording from cells and cell free membrane patches. Pfluegers Arch 391:85-100.

Hirano $T$ (1990) Effects of postsynaptic depolarization in the induction of synaptic depression between a granule cell and a Purkinje cell in rat cerebellar culture. Neurosci Lett 119:145-147

Hirano T, Hagiwara S (1989) Kinetics and distribution of voltagegated $\mathrm{Ca}, \mathrm{Na}$, and $\mathrm{K}$ channels on the somata of rat cerebellar Purkinje cells. Pfluegers Arch 413:463-469.

Hirano T, Ohmori H (1986) Voltage-gated and synaptic currents in rat Purkinje cells in dissociated cell cultures. Proc Natl Acad Sci USA 83:1945-1949.

Hockberger PE, Tseng H-Y, Connor JA (1989a) Development of rat cerebellar Purkinje cells: electrophysiological properties following acute isolation and in long term culture. $J$ Neurosci 9:2258-2271.

Hockberger PE, Tseng H-Y, Connor JA (1989b) Fura-2 measurements of cultured rat Purkinje neurons show dendritic localization of $\mathrm{Ca}^{2+}$ influx. J Neurosci 9:2272-2284

Huang PM, Bredt DS, Snyder SH (1990) Autoradiographic imaging of phosphoinositide turnover in brain. Science 249:802-804.

Hughes $\Lambda \mathrm{D}$, Herling $\mathrm{S}$, Bolton TB (1990) The action of caffeine on inward barium current through voltage dependent calcium channels in single rabbit ear artery cells. Pfluegers Arch 416:462-466.
Irving AJ, Schofield JG, Watkins JC, Sunter DC, Collingridge GL (1990) $1 S, 3 R$-ACPD stimulates and L-AP3 blocks $\mathrm{Ca}^{2+}$ mobilization in rat cerebellar neurons. Eur J Pharmacol 186:363-365.

Kaneda M, Wakamori M, Ito C, Akaike N (1990) Low-threshold calcium current in isolated Purkinje cell bodies of rat cerebellum. $\mathbf{J}$ Neurophysiol 63:1046-1051.

Kapoor R, Jaeger CB, Llinas R (1988) Electrophysiology of the mammalian cerebellar cortex in organ culture. Neuroscience 26:493-507.

Knopfel T, Vranesic I, Staub C, Gähwiler BH (1991) Climbing fiber responses in olivo-cerebellar slice cultures II. Dynamics of cytosolic calcium in Purkinje cells. Eur J Neurosci 3:343-348.

Krupa M, Crepel F (1990) Transient sensitivity of rat cerebellar Purkinje cells to $N$-methyl-D-aspartate during development. A voltage clamp study in in vitro slices. Eur J Neurosci 2:312-316.

Lasser-Ross N, Miyakawa H, Lev-Ram V, Young SR, Ross WN (1991) High time resolution fluorescence imaging with a CCD camera. J Neurosci Methods 36:253-261.

Legrand CH, Thomasset M, Parkes CO, Clavel MC, Rabie A (1983) Calcium-binding protein in the developing rat cerebellum. An immunocytochemical study. Cell Tissue Res 233:389-402.

Llano I, Marty A, Armstrong CM, Konnerth A (1991) Synaptic and agonist induced excitatory currents of Purkinje cells in rat cerebellar slices. J Physiol (Lond) 434:183-213.

Llinas R, Sugimori M (1980a) Electrophysiological properties of in vitro Purkinje cell somata in mammalian cerebellar slices. J Physio (Lond) 305:171-195.

Llinas R, Sugimori M (1980b) Electrophysiological properties of in vitro Purkinje cell dendrites in mammalian cerebellar slices. J Physiol (Lond) 305:197-213.

Maeda N, Niinobe M, Mikoshiba K (1990) A cerebellar Purkinje cell marker P400 protein is an inositol 1,4,5-trisphosphate (InsP3) receptor protein. Purification and characterization of InsP3 receptor complex. EMBO J 9:61-67.

Maeda N, Kawasaki T, Nakade S, Yokota N, Taguchi T, Kasai M, Mikushiba K (1991) Structural and functional characterization of inositol 1,4,5-trisphosphate receptor channel from mouse cerebellum. J Biol Chem 266:1109-1116.

Masu M, Tanabe Y, Isuchida K, Shigemoto K, Nakanishi S (1991) Sequence and expression of a metabotropic glutamate receptor. Nature 349:760-765.

Mathers DA, Barker JC (1984) Spontaneous voltage and current fluctuations in tissue cultured mouse dorsal root ganglion cells. Brain Res 293:35-47.

Mayer ML, Miller RJ (1990) Excitatory amino acid receptors: regulation of neuronal $\left[\mathrm{Ca}^{2+}\right]$ and other second messengers. Trends Pharmacol Sci 11:254-260.

McPherson PS, Campbell KP (1990) Solubilization and biochemical characterization of the high affinity $\left[{ }^{3} \mathrm{H}\right]$ ryanodine receptor from rabbit brain membranes. J Biol Chem 265:18454-18460.

Mignery GA, Sudhof TC, Takei K, De Camilli P (1989) Putative receptor for inositol-1,4,5-trisphosphate similar to ryanodine receptor. Nature 342:192-195.

Miller RJ (1991) The control of neuronal $\mathrm{Ca}^{2+}$ homeostasis. Prog Neurobiol 37:255-285.

Monaghan PL, Beitz AJ, Larson AA, Altschuler RA, Madl JE, Mullett MA (1986) Immunocytochemical localization of glutamate-, glutaminase- and aspartate aminotransferase-like immunoreactivity in the rat deep cerebellar nuclei. Brain Res 363:364-370.

Murphy SN, Miller RJ (1988) A glutamate receptor regulates $\mathrm{Ca}^{2+}$ mobilization in hippocampal neurons. Proc Natl Acad Sci USA 85: 8737-8741.

Murphy SN, Miller RJ (1989) Two distinct quisqualate receptors regulate $\mathrm{Ca}^{2+}$ homeostasis in hippocampal neurons in vitro. Mol Pharmacol 35:671-680.

Peng Y-W, Sharp AH, Snyder SH, Yau K-W (1991) Localization of the inositol 1,4,5-trisphosphate receptor in synaptic terminals in the vertebrate retina. Neuron 6:525-531.

Perkel DJ, Hestrin S, Sah P, Nicoll RA (1990) Excitatory synaptic currents in Purkinje cells. Proc R Soc Lond [Biol] 241:116-121.

Plessers L, Eggermont JA, Wuytack F, Casteels R (1991) A study of the organeller $\mathrm{Ca}^{2+}$ transport ATPase isozymes in pig cerebellar neurons. J Neurosci 11:650-656.

Regan LJ (1991) Voltage-dependent calcium currents in Purkinje cells from rat cerebellar vermis. J Neurosci 11:2259-2269.

Regan LJ, Sah DWY, Bean BP (1991) Calcium channels in rat central 
and peripheral neurons: high threshold current resistant to dihydropyridine blockers and $\omega$-conotoxin. Neuron 6:269-280.

Rogers JH (1989) Immunoreactivity for calretinin and other calciumbinding proteins in cerebellum. Neuroscience 31:711-721.

Ross CA, Meldolesi J, Milner TA, Tomohide S, Supattapone S, Snyder SH (1989) Inositol 1,4,5-trisphosphate receptor localized to endoplasmic reticulum in cerebellar Purkinje neurons. Nature 339:468470.

Ross WN, Werman R (1987) Mapping calcium transients in the dendrites of Purkinje cells from the guinea-pig cerebellum in vitro. $\mathrm{J}$ Physiol (Lond) 389:319-336.

Ross WN, Lasser-Ross N, Werman R (1990) Spatial and temporal analysis of calcium-dependent electrical activity in guinea-pig Purkinje cell dendrites. Proc R Soc Lond [Biol] 240:173-185.

Sakurai M (1987) Synaptic modification of parallel fiber-Purkinje cell transmission in in vitro guinea-pig cerebellar slices. J Physiol (Lond) 394:463-480.

Sakurai M (1990) Calcium is an intracellular mediator of the climbing fiber in induction of cerebellar long-term depression. Proc Natl Acad Sci USA 87:3383-3385.

Satin LS, Adams PR (1987) Spontaneous miniature outward currents in cultured bullfrog neurons. Brain Res 401:331-339.

Satoh T, Ross CA, Villa A, Supattapone S, Pozzan T, Snyder SH, Mcldolcsi J (1990) The inositol 1,4,5-trisphosphate receptor in cerebellar Purkinje cells: quantitative immunogold labeling reveals concentration in an ER subcompartment. J Cell Biol 111:615-624.

Schoepp D, Bockaert J, Sladeczek F (1990) Pharmacological and functional characteristics of metabotropic excitatory amino acid receptors. Trends Pharmacol Sci 11:508-515.

Scholz WK, Baitinger C, Schulman H, Kelly PT (1988) Developmental changes in $\mathrm{Ca}^{2+} /$ calmodulin dependent kinase II in cultures of hippocampal neurons and astrocytes. J Neurosci 8:1039-1051.

Sequier JM, Hunziker W, Andressen C, Celio MR (1990) Calbindin D-28k protein and mRNA localization in the rat brain. Eur J Neurosci 2:1118-1126.
Sorimachi M, Nishimura S, Kuramoto K (1991) Receptor types mediating the rise in the cytosolic free calcium concentration by L-aspartate and L-glutamate in immature cerebellar neurons with $N$-methyl-D-aspartate receptors. Brain Res 543:166-169.

Sugimori M, Llinas RR (1990) Real-time imaging of calcium influx in mammalian cerebellar Purkinje cells in vitro. Proc Natl Acad Sci USA 87:5084-5088.

Tank DW, Sugimori M, Connor JA, Llinas RR (1988) Spatially resolved calcium dynamics of mammalian Purkinje cells in cerebellar slices. Science 242:773-777.

Thayer SA, Hirning LD, Miller RJ (1988a) The role of caffeine-sensitive calcium stores in the regulation of the intracellular free calcium concentration in rat sympathetic neurons in vitro. Mol Pharmacol 34: 664-673.

Thayer SA, Sturek M, Miller RJ (1988b) Measurement of neuronal $\mathrm{Ca}^{2+}$ transients using simultaneous microfluorimetry and electrophysiology. Pfluegers Arch 412:216-223.

Thayer SA, Perney TM, Miller RJ (1988c) Regulation of calcium homeostasis in sensory neurons by bradykinin. J Neurosci 8:40894097.

Wassef M, Zanetta JP, Brehier A, Sotelo C (1985) Transient biochemical compartmentalization of Purkinje cells during early cerebellar development. Dev Biol 111:129-137.

Weber A, Schachner M (1984) Maintenance of immunocytologically identified Purkinje cells from mouse cerebellum in monolayer culture. Brain Res 311:119-130.

Yool AJ, Dionne VE, Gruol DL (1988) Devclopmental changes in $\mathrm{K}^{+}$-selective channel activity during differentiation of the Purkinje neuron in culture. J Neurosci 8:1971-1980.

Yuzaki M, Kudo Y, Akita K, Miyawaki A, Mikoshiba K (1990) MK801 blocked the functional NMDA receptors in identified cerebellar neurons. Neurosci Lett 119:19-22. 